\title{
CALIPSO level 3 stratospheric aerosol profile product: version 1.00 algorithm description and initial assessment
}

\author{
Jayanta Kar ${ }^{1,2}$, Kam-Pui Lee ${ }^{1,2}$, Mark A. Vaughan ${ }^{2}$, Jason L. Tackett ${ }^{2}$, Charles R. Trepte ${ }^{2}$, David M. Winker ${ }^{2}$, \\ Patricia L. Lucker ${ }^{1,2}$, and Brian J. Getzewich ${ }^{1,2}$ \\ ${ }^{1}$ Science Systems and Applications Inc., Hampton, VA, USA \\ ${ }^{2}$ Science Directorate, NASA Langley Research Center, Hampton, VA, USA
}

Correspondence: Jayanta Kar (jayanta.kar@nasa.gov)

Received: 13 June 2019 - Discussion started: 25 June 2019

Revised: 26 September 2019 - Accepted: 7 October 2019 - Published: 25 November 2019

\begin{abstract}
In August 2018, the Cloud-Aerosol Lidar and Infrared Pathfinder Satellite Observation (CALIPSO) project released a new level 3 stratospheric aerosol profile data product derived from nearly 12 years of measurements acquired by the spaceborne Cloud-Aerosol Lidar with Orthogonal Polarization (CALIOP). This monthly averaged, gridded level 3 product is based on version 4 of the CALIOP level 1B and level 2 data products, which feature significantly improved calibration that now makes it possible to reliably retrieve profiles of stratospheric aerosol extinction and backscatter coefficients at $532 \mathrm{~nm}$. This paper describes the science algorithm and data handling techniques that were developed to generate the CALIPSO version 1.00 level 3 stratospheric aerosol profile product. Further, we show that the extinction profiles (retrieved using a constant lidar ratio of $50 \mathrm{sr}$ ) capture the major stratospheric perturbations in both hemispheres over the last decade resulting from volcanic eruptions, extreme smoke events, and signatures of stratospheric dynamics. Initial assessment of the product by intercomparison with the stratospheric aerosol retrievals from the Stratospheric Aerosol and Gas Experiment III (SAGE III) on the International Space Station (ISS) indicates good agreement in the tropical stratospheric aerosol layer $\left(30^{\circ} \mathrm{N}-30^{\circ} \mathrm{S}\right)$, where the average difference between zonal mean extinction profiles is typically less than $25 \%$ between 20 and $30 \mathrm{~km}$ (CALIPSO biased high). However, differences can exceed $100 \%$ in the very low aerosol loading regimes found above $25 \mathrm{~km}$ at higher latitudes. Similarly, there are large differences $(\geq 100 \%)$ within 2 to $3 \mathrm{~km}$ above the tropopause that might be due to cloud contamination issues.
\end{abstract}

\section{Introduction}

While the bulk of the global distribution of atmospheric aerosols is concentrated within the planetary boundary layer and free troposphere, the persistent aerosol burden in the stratosphere has long been known to have important implications for Earth's climate (Turco et al., 1980). Techniques for the reliable detection of a background aerosol layer in the stratosphere date back to the early 1960s (Junge and Manson, 1961). These aerosols are mostly liquid sulfate particles that are derived from precursor gases like $\mathrm{SO}_{2}$ and carbonyl sulfide (OCS) transported from the troposphere (Thomason and Peter, 2006; Kremser et al., 2016; Thomason et al., 2018). In addition, intermittent volcanic eruptions and strong biomass burning events can inject sulfates, ash, and smoke into the stratosphere, which can last for long periods of time and exert significant climatic influences. For example, stratospheric perturbations from the Pinatubo volcano in 1991 lasted for several years (Chazette et al., 1995; Robock, 2000; Deshler, 2008). While eruptions of the same scale as Pinatubo have not taken place in the last 25 years or so, there is evidence that a large number of smaller eruptions has been significantly affecting the stratosphere with implications for the climate system (Vernier et al., 2011a; Solomon et al., 2011). Thus it is very important to monitor stratospheric aerosol loading over the long term. In pursuit of this goal, stratospheric aerosol measurements have been made using numerous techniques, including ground-based lidars, balloon-borne in situ samplers, and multi-sensor aircraft measurements, since the mid-twentieth century (Junge and Manson, 1961; Northam et al., 1974; Hoffman et al., 1975; McCormick et al., 1984; 
Grams and Fiocco, 1986; Brock et al., 1993; Beyerle et al., 1994; Jaeger and Deshler, 2002).

Most of our current knowledge of the global distribution of stratospheric aerosols comes from satellite measurements. The earliest of such measurements were carried out by the Stratospheric Aerosol Measurement II (SAM II) onboard the Nimbus 7 spacecraft, which provided vertical profiles of aerosol extinction at $1 \mu \mathrm{m}$, and were followed by the Stratospheric Aerosol and Gas Experiment (SAGE) series of instruments (Chu and McCormick, 1979; Kent and McCormick, 1984; Mauldin III et al., 1985; Chu et al., 1989; Damadeo et al., 2013). The basic principle employed in these instruments is solar occultation, whereby the vertical profile of stratospheric aerosols is retrieved from the measurement of sunlight as the rays pass through the atmosphere during sunrise and sunset events as observed from the orbiting spacecraft. Stratospheric aerosols have been characterized using this technique from SAGE instruments on the Earth Radiation Budget Satellite (ERBS) and Meteor-3M as well as from the International Space Station (ISS). Among other spaceborne instruments that have used this technique are the Polar Ozone and Aerosol Measurement (POAM II, POAM III; Glaccum et al., 1996; Lucke et al., 1999) and Measurement of Aerosol Extinction in the Stratosphere and Troposphere Retrieved by Occultation (MAESTRO; McElroy et al., 2007). In addition, the Optical Spectrograph and InfraRed Imager System (OSIRIS) and the Ozone Mapping and Profiler Suite (OMPS) have used a limb scatter technique to obtain aerosol extinction profiles (Bourassa et al., 2012; Chen et al., 2018).

A novel and pioneering technique to retrieve aerosol profiles from space came about with the launch of the CloudAerosol Lidar and Infrared Pathfinder Satellite Observation (CALIPSO) mission in April 2006, with a two-wavelength, polarization-sensitive elastic backscatter lidar as the primary payload (Winker et al., 2010). For over 12 years the CloudAerosol Lidar with Orthogonal Polarization (CALIOP) has been providing vertically resolved profiles of aerosol and cloud extinction globally. The primary measurement from a spaceborne elastic backscatter lidar consists of the attenuated backscatter coefficients of the aerosols and clouds in the atmosphere. The strong backscatter from the tropospheric aerosols, combined with CALIOP's relatively strong signalto-noise ratio (SNR), has been exploited to provide accurate extinction profiles in the troposphere (Young and Vaughan, 2009; Winker et al., 2013; Young et al., 2013, 2016, 2018). In comparison, the aerosol loading in the stratosphere is much lower with correspondingly smaller SNR. As such, retrieving stratospheric aerosol information was not originally a principal target of the CALIPSO mission. However, early results indicated that it might be possible to obtain such information with sufficient averaging of the data (Thomason et al., 2007; Vernier et al., 2009).

One of the issues impacting the retrieval of stratospheric aerosol extinction was the realization that the standard cal- ibration altitude of CALIOP, which was originally fixed at $30-34 \mathrm{~km}$ (Powell et al., 2009), was not completely free of aerosols, and thus applying the molecular normalization technique at these altitudes would bias the aerosol extinction profiles (Vernier et al., 2009). This issue has since been addressed with the release of the version 4 (V4) family of CALIPSO data products in November 2016. In this version, the calibration altitude for the nighttime $532 \mathrm{~nm}$ data, which is the primary calibration for all CALIOP measurements (all other measurements like the daytime data as well as the $1064 \mathrm{~nm}$ data are calibrated relative to the $532 \mathrm{~nm}$ nighttime calibration), was raised to $36-39 \mathrm{~km}$, where the aerosol loading is expected to be negligible (Kar et al., 2018a). This largely removed the aerosol contamination issue, making reliable retrievals of stratospheric aerosols possible. Accordingly, a stand-alone CALIPSO stratospheric aerosol profile product was developed that uses the V4 level 1B and level 2 data from the CALIOP measurements. This is a level 3 monthly averaged product gridded in latitude $\left(5^{\circ}\right)$, longitude $\left(20^{\circ}\right)$, and altitude $(900 \mathrm{~m})$. In what follows, we describe the overall algorithm and its implementation in detail in Sect. 2. Section 3 then presents a comprehensive assessment of the quality and capabilities of this new data product, including analyses of the temporal and spatial evolution of specific stratospheric features captured by the product and intercomparisons with extinction retrievals from SAGE III on ISS. A discussion and concluding remarks are given in Sects. 4 and 5 , respectively.

\section{Overall design of the level 3 stratospheric aerosol profile product}

\subsection{Motivation for a CALIPSO stratospheric product}

The CALIPSO level 3 stratospheric aerosol profile product is built primarily from the V4 level 1B $532 \mathrm{~nm}$ attenuated backscatter profiles (https://eosweb.larc.nasa. gov/project/calipso/cal_lid_11-standard-v4-10, last access: 13 November 2019). As mentioned above, the most fundamental change in V4 level 1 data was the improved calibration of the $532 \mathrm{~nm}$ nighttime data (Kar et al., 2018a). The consequences of this change are illustrated in Fig. 1, which shows the median values of zonally averaged attenuated scattering ratios at $30-34 \mathrm{~km}$ from version 3 (V3) and V4 for the month of May 2009.

As shown in Eq. (1), the attenuated scattering ratios, $R^{\prime}(z)$, are computed as the ratio of the measured attenuated backscatter coefficients, $\beta^{\prime}$ measured $(z)$, which contain contributions from both molecular and particulate backscatter $\left(\beta_{\mathrm{m}}(z)\right.$ and $\beta_{\mathrm{p}}(z)$, respectively), and the attenuated backscatter coefficients calculated from modeled profiles of molecu- 


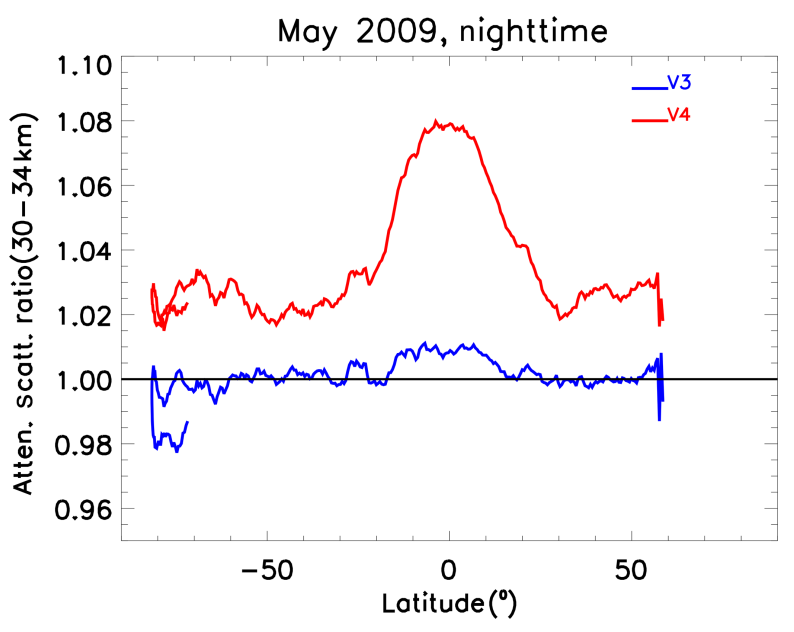

Figure 1. Median values of zonally and vertically (over 30-34 km) averaged $532 \mathrm{~nm}$ attenuated scattering ratios for May 2009 nighttime data from V3 and V4. Data over the South Atlantic Anomaly were excluded. A 10-point smoothing of the data has been applied.

lar number densities, $\beta^{\prime}$ modeled $(z)$ (Vaughan et al., 2009).

$$
\begin{aligned}
R^{\prime}(z) & =\frac{\beta_{\text {measured }}^{\prime}(z)}{\beta_{\text {modeled }}^{\prime}(z)} \\
& =\frac{\left(\beta_{\mathrm{m}}(z)+\beta_{\mathrm{p}}(z)\right) T_{\mathrm{m}}^{2}(z) T_{\mathrm{O}_{3}}^{2}(z) T_{\mathrm{p}}^{2}(z)}{\beta_{\mathrm{m}, \text { modeled }}(z) T_{\mathrm{m}, \text { modeled }}^{2}(z) T_{\mathrm{O}_{3}, \text { modeled }}^{2}(z)} \\
& =\left(1+\frac{\beta_{\mathrm{p}}(z)}{\beta_{\mathrm{m}, \text { modeled }}(z)}\right) T_{\mathrm{p}}^{2}(z)
\end{aligned}
$$

In this expression, $T_{X}^{2}(z)$ represents the two-way transmittance (i.e., signal attenuation) between the lidar and altitude $z$ for air molecules $(X=\mathrm{m})$, ozone $\left(X=\mathrm{O}_{3}\right)$, and particulates $(X=\mathrm{p})$. In V3, the calibration region was fixed at 30$34 \mathrm{~km}$, with the assumption that the aerosol loading in this region was negligible (Powell et al., 2009); i.e., $\beta_{\mathrm{p}}(z) \approx 0$ and $T_{\mathrm{p}}^{2}(z)=1$. This assumption essentially forced the V3 attenuated scattering ratios in the region to 1 . For the V4 data release, the calibration region was raised to $36-39 \mathrm{~km}$, with the concomitant assumption that the mean scattering ratio at these higher altitudes is $1.01 \pm 0.01$. The $\mathrm{V} 4$ attenuated scattering ratios now (correctly) show significant aerosol in the altitude region used for the V3 calibration, with a strong maximum appearing over the tropics (Fig. 1). The V4 data also capture the seasonal variation of these scattering ratios (Kar et al., 2018a, see their Fig. 12). This improved calibration in $\mathrm{V} 4$, now accurate to about $1.6 \%$, provides the motivation for the development of the CALIPSO stratospheric product, as it enables the retrieval of aerosol extinction coefficients in regions previously (but incorrectly) assumed to be aerosol-free (Kar et al., 2018a).

\subsection{Design and algorithm description}

The level 3 stratospheric aerosol profile product reports height-resolved monthly mean profiles of aerosol backscatter and extinction coefficients on a uniform spatial grid that extends $5^{\circ}$ in latitude (from $85^{\circ} \mathrm{N}$ to $85^{\circ} \mathrm{S}$ ), $20^{\circ}$ in longitude (from $180^{\circ} \mathrm{W}$ to $180^{\circ} \mathrm{E}$ ), and $900 \mathrm{~m}$ in altitude. Given the low SNR in the stratospheric backscatter measurements, it is necessary to average the data substantially, both spatially and temporally. Averaging the backscatter data over $5^{\circ}$ in latitude increases the SNR by a factor of 40 (compared to single shot profiles) and provides a reasonable depiction of stratospheric aerosol distribution. This is also consistent with the early results of Thomason et al. (2007), who used the early CALIPSO measurements together with data from the CALIPSO simulator (Powell, 2005) to show that averaging the data over $5^{\circ}$ in latitude and about $1 \mathrm{~km}$ in the vertical resulted in fairly representative stratospheric distribution. Further, the spatial distributions of stratospheric species tend to be zonally symmetric (e.g., Kremser et al., 2016). In order to capture the signature of any possible longitudinal variation, e.g., the Asian tropopause aerosol layer (ATAL) that occurs over Asia every summer during the monsoon months, we have used a longitudinal grid of $20^{\circ}$. The altitude resolution of the CALIOP level 1 profiles varies with altitude from $60 \mathrm{~m}$ between 8.3 and $20.2 \mathrm{~km}$ to $180 \mathrm{~m}$ between 20.2 and $30.1 \mathrm{~km}$ and finally to $300 \mathrm{~m}$ between 30.1 and $40.0 \mathrm{~km}$. In order to achieve a uniform altitude resolution, the vertical grid resolution was set to $900 \mathrm{~m}$. Note that the tropopause can occur below $8.3 \mathrm{~km}$ at high latitudes, but the vertical resolution of level 1 profiles changes again below this altitude, and the lower limit was kept at $8.3 \mathrm{~km}$ as a trade-off between computational complexity and the stratospheric information content, while the upper limit was set at $36 \mathrm{~km}$, which is the lower limit of the calibration region. The tropopause heights were taken from the Modern-Era Retrospective analysis for Research and Applications 2 (MERRA-2) reanalyses as in all V4 products (Gelaro et al., 2017). In the current version of the stratospheric aerosol product we use only nighttime data as they have significantly better SNR compared to the daytime data (Hunt et al., 2009).

Each level 3 stratospheric aerosol file reports two distinct realizations of the monthly averaged data products. The first of these is the "background" mode, which is designed to represent the long-term background stratospheric aerosol loading. In order to achieve this, we need to remove all readily detectable perturbations within the stratosphere, such as overshooting cirrus clouds, polar stratospheric clouds (PSCs), and strongly scattering injections of smoke, volcanic ash, and other aerosol species that are detected using the layer detection algorithm implemented in the CALIOP level 2 data processing (Vaughan et al., 2009). The second realization is the "all-aerosol" mode, which is designed to represent the time history of aerosol loading in the stratosphere resulting from all possible sources. In this case, the clouds and PSCs are still 
removed, exactly as is done for the background mode; however, subject to various quality assurance tests, the aerosol layers detected in the level 2 analyses are retained. Details of the averaging algorithms and the various data filtering schemes are provided in the following sections.

\subsubsection{Gridding and filtering}

The overall design of the level 3 stratospheric aerosol product is shown in Fig. 2. To begin with, three input files are required for each granule under consideration. A CALIOP granule comprises half an orbit of data either from the daytime or the nighttime part of the orbit and divided by the day-night terminator. As noted in Sect. 1, the primary input files used for the present product are the lidar level 1B file, with the corresponding level $25 \mathrm{~km}$ merged layer and PSC mask files (Pitts et al., 2009) used for filtering. While the levels $1 \mathrm{~B}$ and 2 merged layer files are based on V4, the currently available level 2 PSC files are based on V3. The latter is only available as a daily file and not for each granule separately. The $5 \mathrm{~km}$ merged layer file is a new product in V4 that reports the locations of all aerosol and cloud layers detected at both $5 \mathrm{~km}$ (also 20 and $80 \mathrm{~km}$ ) and single shot $(333 \mathrm{~m})$ resolution (Vaughan et al., 2016).

In the background mode, clearing the features detected in the level 2 analyses is done by removing all the level 1B (L1B) attenuated backscatter values (for 15 consecutive L1B profiles) beginning at the top of the uppermost cloud or aerosol layers detected above the local tropopause using the layer heights reported in the $5 \mathrm{~km}$ merged layer file. Not only are signals from within the boundary of the layers removed, but the backscatter values at all altitudes below the layers are also removed to avoid issues in correcting for signal attenuation from overlying layers. While the attenuated backscattered signals within and below these layers are removed, this step will retain values that fall below the minimum detectable attenuated backscatter threshold of the CALIPSO layer detection algorithm (McGill et al., 2007). In this sense, the retrieved extinction in this mode will reflect only the aerosol loading below this threshold. Similarly, the signals below the uppermost PSC layers are also removed using the PSC mask file for the PSC-active months in the two hemispheres (December through March in the Arctic and May through October in the Antarctic). The PSC mask files report the occurrence of PSCs in both hemispheres (Pitts et al., 2007, 2009) and are reported for a single day on a $5 \mathrm{~km}$ horizontal and $180 \mathrm{~m}$ vertical grid for nighttime conditions only.

After clearing all level 2 and PSC layers detected above the local tropopause, all L1B attenuated backscatter values below the tropopause are removed. Further, all L1B profiles within the South Atlantic Anomaly (SAA) region are also removed. In this region, approximately between the Equator and $50^{\circ} \mathrm{S}$ in latitude and $20^{\circ} \mathrm{E}$ to $80^{\circ} \mathrm{W}$ in longitude (in the operational algorithm a polygon is used), the Van Allen belts come down to their lowest altitude $(<200 \mathrm{~km})$, thus expos- ing the satellite sensors to high fluxes of energetic charged particles that are trapped within the belts (Hunt et al., 2009; Noel et al., 2014). Large-amplitude noise excursions are often observed in attenuated backscatter profiles within this area, thus degrading the already low SNR in the stratosphere. Consequently, data over the SAA are not included when calculating the level 3 stratospheric aerosol product.

When creating the all-aerosol mode of the stratospheric aerosol product, it is necessary to remove any clouds and PSCs, much the same way as for the background case, but retain the detected layers classified as aerosols by the CALIPSO cloud-aerosol discrimination (CAD) algorithm (Liu et al., 2009, 2019). It should be mentioned that the CAD algorithm was also modified in V4 in order to be compatible with the new V4 $532 \mathrm{~nm}$ calibration (Liu et al., 2019). In fact, the CAD algorithm was extended to the stratosphere for the first time in V4. Up until V3, any layer in the stratosphere was simply classified as a "stratospheric feature" and no distinction was made between clouds and aerosols, which is no longer the case in V4. However, even the V4 CAD algorithm may not perform very well at high altitudes because of low SNR, leading to generally lower absolute values of CAD scores (Liu et al., 2019). In any case, in the stratospheric altitudes above $\sim 20 \mathrm{~km}$, clouds are seldom observed (except in the polar regions) and uncertainties in the CAD algorithm are not likely to affect the stratospheric aerosol product. For this mode, only aerosol layers with acceptable CAD scores $(-100$ to -20$)$ are retained within the stratosphere. Layers identified as aerosols but with unacceptably low CAD scores (between 0 and -20 ) are removed as if they were clouds or PSCs.

In the next step, a nominal $5 \mathrm{~km}$ resolution profile is constructed by taking the average of these 15 filtered L1B attenuated backscatter profiles. Subsequently, a noise filter is used to screen out strong outliers from these $5 \mathrm{~km}$ profiles that might otherwise lead to biases in high-latitude and/or high-altitude regions. The noise filter used for the current version of the product is a reconfigured version of the same filter that is used in the CALIPSO range-dependent automated level 2 layer detection algorithm. Essentially a rangedependent threshold array of attenuated scattering ratios is constructed, which incorporates noise from two types of sources. The first category is the range invariant noise and includes detector dark noise and noise from the solar background light. The second category is the range-dependent noise from single shot measurements and is calculated from the molecular models. Using this range-dependent threshold, outliers are removed (for details see Vaughan et al., 2009, Sect. 2c). After removing the outliers, the $5 \mathrm{~km}$ profile is assigned to the appropriate spatial grid. This process is then repeated for all the profiles in the level $1 \mathrm{~B}$ file. The resulting filtered $5 \mathrm{~km}$ profiles are then averaged to create a single mean attenuated backscatter profile for each grid cell.

In the final processing step for each granule, another quality screening is employed to identify and remove any linger- 


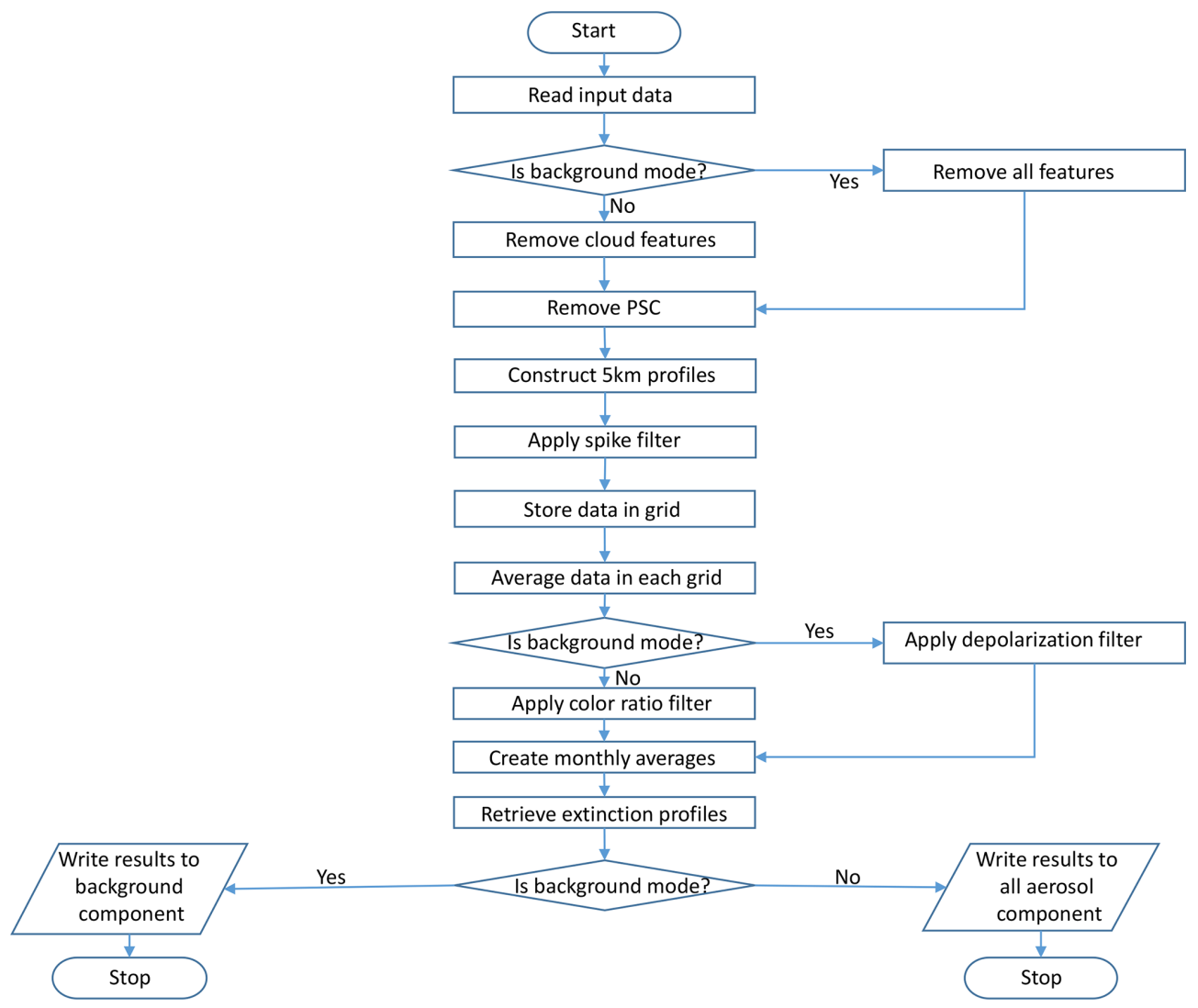

Figure 2. Flowchart illustrating the overall design of the CALIPSO level 3 stratospheric aerosol profile product.

ing tenuous cirrus cloud in the lower stratosphere that might have escaped the layer detection mechanism due to low backscatter values. For the background mode, we can safely assume that the background aerosols are uniformly spherical and thus have a near-zero depolarization ratio. Since ice crystals in even the most tenuous cirrus violate this assumption, we use a threshold of $5 \%$ in the volume depolarization ratio (ratio of the attenuated backscatter measured in the perpendicular and parallel channels at $532 \mathrm{~nm}$; Hunt et al., 2009) to detect weakly scattering residual clouds. However, for the all-aerosol mode, this strategy will not work. This is because volcanic ash is typically nonspherical, has high volume depolarization values $(\sim 25 \%-30 \%)$, and would thus be removed along with the cirrus clouds. On the other hand, attenuated color ratio values (i.e., the ratio of the total attenuated backscatter coefficients at 1064 and $532 \mathrm{~nm}$ ) are generally larger for clouds compared to volcanic ash and may thus be used to filter out clouds while still retaining volcanic ash (Winker et al., 2012; Vernier et al., 2013). We have used a threshold value of 0.5 in the attenuated color ratio in the allaerosol mode in an attempt to retain the volcanic ash rather than the filter on the volume depolarization ratio. The effects of these filters in both modes are illustrated in Fig. 3 using height-latitude cross sections of attenuated scattering ratios for the month of June 2011.
During this month two strong volcanic eruptions took place, Nabro in the Northern Hemisphere (13 June; $13^{\circ} \mathrm{N}$, $41^{\circ} \mathrm{E}$ ) and Puyehue-Cordón Caulle in the Southern Hemisphere (4 June; $40^{\circ} \mathrm{S}, 72^{\circ} \mathrm{W}$ ). The composition of the Nabro plume was mostly sulfate, while the composition of Puyehue-Cordón Caulle was mostly ash, at least initially (Penning de Vries et al., 2014; Vernier et al., 2013). In the background mode (Fig. 3a), the removal of all detected layers combined with the application of the volume depolarization filter ensures that stratospheric perturbations from these two volcanoes are mostly excluded. Figure $3 \mathrm{~b}$ shows the effect of including aerosol layers in the stratosphere with acceptable CAD scores $(|\mathrm{CAD}|>20)$ while still using the volume depolarization filter. Now the Nabro plume can be clearly seen but not that of Puyehue-Cordón Caulle. This is because the sulfates in the Nabro plume have low volume depolarization ratios that fall below the threshold and are thus retained, while the ash layers with a high volume depolarization ratio from Puyehue-Cordón Caulle are removed. On the other hand, including the aerosol layers but substituting an attenuated color ratio threshold of 0.5 in place of the volume depolarization ratio filter, as shown in Fig. 3c (all-aerosol mode), reveals both the Nabro (near $30^{\circ} \mathrm{N}$ ) and Puyehue-Cordón Caulle plumes (near $50^{\circ} \mathrm{S}$ ) quite clearly. Note the high scattering ratio values in the Antarctic latitudes between 15 and 

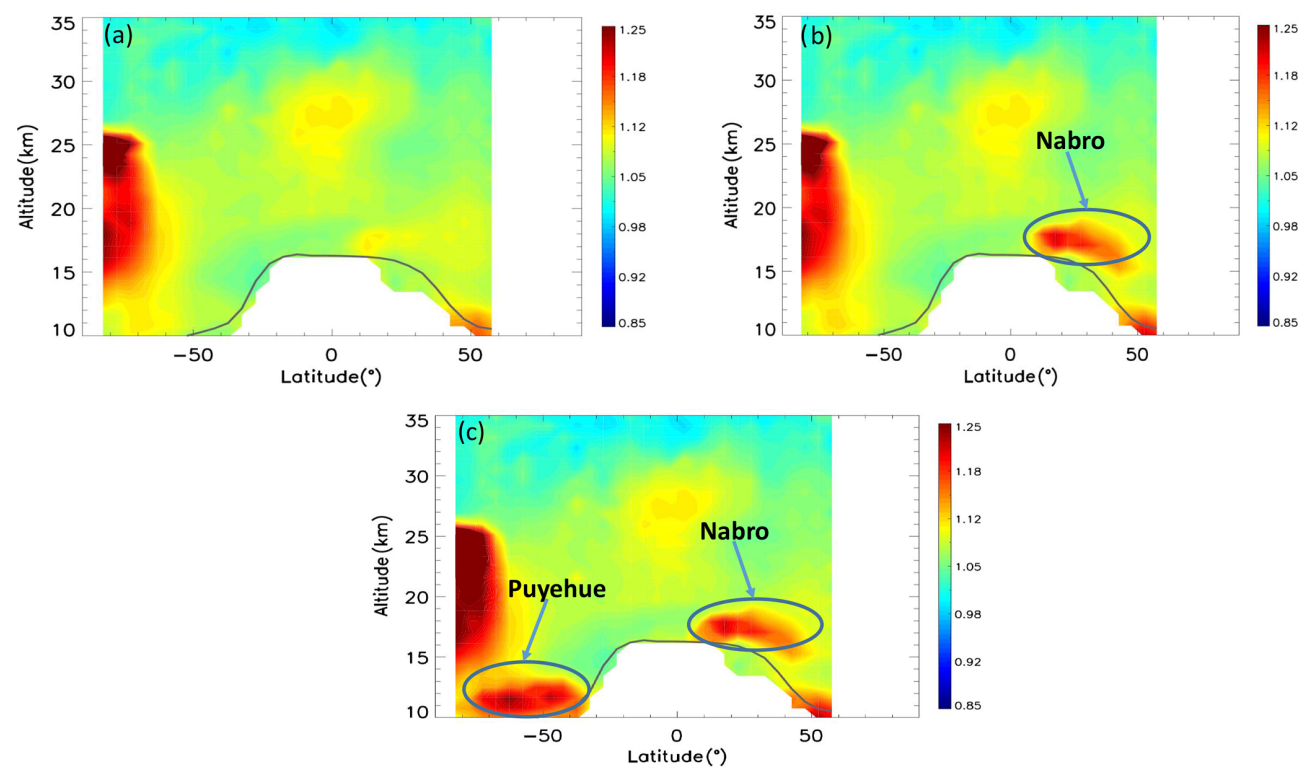

Figure 3. Zonally averaged height-latitude cross sections of attenuated scattering ratio for June 2011: (a) after removing all detected layers and using a volume depolarization ratio filter (i.e., background aerosol only); (b) including aerosol layers in the stratosphere detected by the level 2 algorithms with a $5 \%$ volume depolarization ratio filter applied; and (c) including the level 2 aerosol layers but using an attenuated color ratio filter instead of the volume depolarization ratio filter. The white area in the northern high latitudes in summer indicates a lack of nighttime data.

$25 \mathrm{~km}$. Because the PSC mask algorithm is optimized specifically for PSC detection, its increased sensitivity allows it to detect a considerably larger fraction of faint PSCs relative to the more generalized and generic level 2 feature detection algorithm. Since all PSC layers detected by the dedicated PSC detection algorithm were removed, what remains are the signatures of only those particles below the detectability threshold of the PSC mask data product. Note that the enhanced scattering ratios near $25-30 \mathrm{~km}$ represent the tropical reservoir of stratospheric aerosols (Trepte and Hitchman, 1992; Kremser et al., 2016). Further, the high scattering ratios near $50^{\circ} \mathrm{N}$ are likely due to the Grímsvötn volcano, which erupted in May 2011.

Using a constant threshold to discriminate between different classes of inherently noisy measurements can entail significant risk of misclassification. For example, using a higher attenuated color ratio acceptance threshold to ensure the identification of strong ash plumes (e.g., for PuyehueCordón Caulle above) may result in a significant amount of cloud contamination. Similarly, an acceptance threshold set too low will likely exclude all clouds while simultaneously discarding much of the ash signal.

The impact of using the attenuated color ratio and volume depolarization ratio filters on removing thin cirrus clouds in the all-aerosol and background-only components, respectively, is illustrated in Fig. 4 using the attenuated scattering ratios measured at $17 \mathrm{~km}$ during December 2011. In Fig. 4a, all the aerosol layers are retained, much like the all-aerosol component, except that neither the volume depolarization ra- tio filter nor the attenuated color ratio filter is used. The high scattering ratios between about 30 and $55^{\circ} \mathrm{N}$ are due to the Nabro plumes that have spread around the Northern Hemisphere by December 2011. Apart from this band, high scattering ratios are also seen in a tropical band (between $25^{\circ} \mathrm{S}$ and $25^{\circ} \mathrm{N}$ ) over the western Pacific as well as over parts of Africa. These reflect the thin cirrus clouds occurring in the upper troposphere and lower stratosphere near the tropopause (Sassen et al., 2009). Figure $4 \mathrm{~b}$ shows the distribution in the all-aerosol mode wherein the attenuated color ratio filter is used. Clearly a significant number of pixels with high scattering ratio (thin cirrus clouds) in the tropics has been removed while still retaining the volcanic aerosol signature. In Fig. 4c we see the impact of the volume depolarization filter in the background mode. Now most of the cirrus clouds have been removed. Note that the aerosol signature has remained much the same in all three distributions. That is because by December 2011, there may not be many volcanic layers left; as such, enhanced scattering from the volcanic material is still present. This figure shows that for quiescent conditions or when the aerosol load is not very high (so that not many plumes are detectable as layers in the CALIPSO L2 algorithm), the volume depolarization filter will do a better job of clearing the thin cirrus clouds, thus making the background component the mode of choice. In any case, note that the thin cirrus clouds mostly affect the tropical latitudes and near the tropopause at $\sim 16-18 \mathrm{~km}$ (Sassen et al., 2009). Note that both the volume depolarization ratio and attenuated 
color ratio filters are applied only below $25 \mathrm{~km}$, as no cirrus is expected above this altitude.

Figure 5 shows the profiles of the attenuated scattering ratio for the background and all-aerosol modes in July 2009 for the grid cell centered at $47.5^{\circ} \mathrm{N}$ and $130^{\circ} \mathrm{E}$. The enhanced scattering ratio in the lower stratosphere between 10 and $17 \mathrm{~km}$ is due to the inclusion of detected aerosol layers from the Sarychev volcano $\left(48.1^{\circ} \mathrm{N}, 153.2^{\circ} \mathrm{E}\right)$, which erupted in June 2009. Note that backscatter from some of the Sarychev aerosols that fall below the minimum detectable backscatter threshold of the level 2 layer detection algorithm will contribute to the background profile.

After deriving the granule-averaged data, we create monthly averaged gridded profiles of attenuated backscatter by aggregating all profiles during each month of the mission. In addition to the attenuated backscatter coefficient profiles, profiles of molecular and ozone number densities, temperatures, and pressures reported in the L1B files are also averaged and gridded for use in the subsequent retrieval procedures.

Figure 6 depicts the spatial distribution of the number of samples that contributed to the two components at $17 \mathrm{~km}$ during July 2009. The grey grid cells over South America and parts of South Atlantic Ocean correspond to the SAA, over which all data samples are rejected. The higher number of samples for the all-aerosol mode over the Asian summer monsoon region reflects the signature of the aerosol in the Asian tropopause aerosol layer (ATAL; Vernier et al., 2011b). A higher number of samples in the all-aerosol mode, albeit to a lesser degree, can also be seen over North America, which is likely related to the Sarychev volcano as mentioned above. Also note the high number of samples over parts of Antarctica, which is partly from oversampling due to orbital configuration and partly related to small particles below the detectability of PSCs by the PSC mask algorithm.

\subsubsection{Retrieval of aerosol extinction profiles}

The monthly mean profiles of the gridded $532 \mathrm{~nm}$ attenuated backscatter coefficient $\left(\beta^{\prime}\right)$, constructed using the procedure described in the preceding section, along with gridded profiles of molecular backscatter coefficients $\left(\beta_{\mathrm{m}}\right)$, molecular extinction coefficients $\left(\alpha_{\mathrm{m}}\right)$, and ozone absorption coefficients $\left(\alpha_{\mathrm{O}_{3}}\right)$, are used to retrieve the particulate backscatter coefficient $\left(\beta_{\mathrm{p}}\right)$ using

$\beta_{\mathrm{p}}(z)=\beta^{\prime}(z) / T_{\mathrm{m}}^{2}(z) T_{\mathrm{O}_{3}}^{2}(z) T_{\mathrm{p}}^{2}(z)-\beta_{\mathrm{m}}(z)$,

where

$$
\begin{aligned}
& T_{\mathrm{m}}^{2}(z)=\exp \left(-2 \int_{0}^{z} \alpha_{\mathrm{m}}\left(r^{\prime}\right) \mathrm{d} r^{\prime}\right), \\
& T_{\mathrm{O}_{3}}^{2}(z)=\exp \left(-2 \int_{0}^{z} \alpha_{\mathrm{O}_{3}}\left(r^{\prime}\right) \mathrm{d} r^{\prime}\right), \text { and }
\end{aligned}
$$

$T_{\mathrm{p}}^{2}(z)=\exp \left(-2 \eta_{\mathrm{p}} S_{\mathrm{p}} \int_{0}^{z} \beta_{\mathrm{p}}\left(r^{\prime}\right) \mathrm{d} r^{\prime}\right)$.

In these expressions, $\eta_{\mathrm{p}}$ is the particulate multiple scattering factor, $S_{\mathrm{p}}$ is the particulate lidar ratio (i.e., the extinction-tobackscatter coefficient ratio), and $T_{\mathrm{m}}^{2}(z), T_{\mathrm{O}_{3}}^{2}(z)$, and $T_{\mathrm{p}}^{2}(z)$ are, as previously defined, the molecular, ozone, and particulate two-way transmittances. The molecular backscatter coefficients and molecular and ozone two-way transmittances can be calculated from molecular model data (e.g., as described in Kar et al., 2018a). The molecular model used exclusively throughout the CALIPSO V4 data products is MERRA-2 provided by NASA's Global Modeling and Assimilation Office (Gelaro et al., 2017). For the CALIPSO stratospheric aerosol product, the particulate multiple scattering factor is taken as 1 for all species of stratospheric aerosols, consistent with the approach taken in the CALIPSO level 2 aerosol retrievals (Young et al., 2013, 2016, 2018).

Given an appropriate value of the lidar ratio, Eqs. (2) and (3c) can be solved iteratively to obtain estimates of $\beta_{\mathrm{p}}(z)$ (Young and Vaughan, 2009). Estimates of particulate extinction coefficients are subsequently obtained using $\sigma_{\mathrm{p}}(z)=S_{\mathrm{p}} \times \beta_{\mathrm{p}}(z)$. The V1.00 release of the level 3 stratospheric aerosol product uses a value of $S_{\mathrm{p}}=50 \mathrm{sr}$ for the stratospheric aerosol lidar ratio, which is a typical value used for stratospheric aerosols for background conditions and in the absence of significant ash and sulfate injections from volcanoes (Trickl et al., 2013; Ridley et al., 2014; Sakai et al., 2016; Kremser et al., 2016; Khaykin et al., 2017). Note that the lidar ratios could also be significantly different for stratospheric perturbations resulting from smoke intrusion from pyroCb events (Peterson et al., 2018; Khaykin et al., 2018). For this first version of the CALIPSO stratospheric aerosol product we have used only a single lidar ratio. We also assume $S_{\mathrm{p}}$ to be constant at all latitudes and over the entire altitude range. The retrievals are carried out beginning at $36 \mathrm{~km}$ and extending downward to either 8.3 or $1 \mathrm{~km}$ below the tropopause; processing stops when the higher of these two altitudes is reached. Extending the range below the tropopause, when possible, is intended to help in studies of the upper troposphere and lower stratosphere (UTLS). To guarantee uniform results across multiple CALIPSO data product levels, the level 2 CALIPSO extinction retrieval module is used to calculate the level 3 profiles of stratospheric aerosol extinction and backscatter coefficients and their uncertainties. The details of the retrieval process and uncertainty estimates are given in Young and Vaughan (2009) and Young et al. $(2013,2016,2018)$ and are not repeated here.

\section{Initial assessment of CALIPSO stratospheric aerosol product}

In this section we assess the initial performance of the CALIPSO stratospheric aerosol product by first presenting 

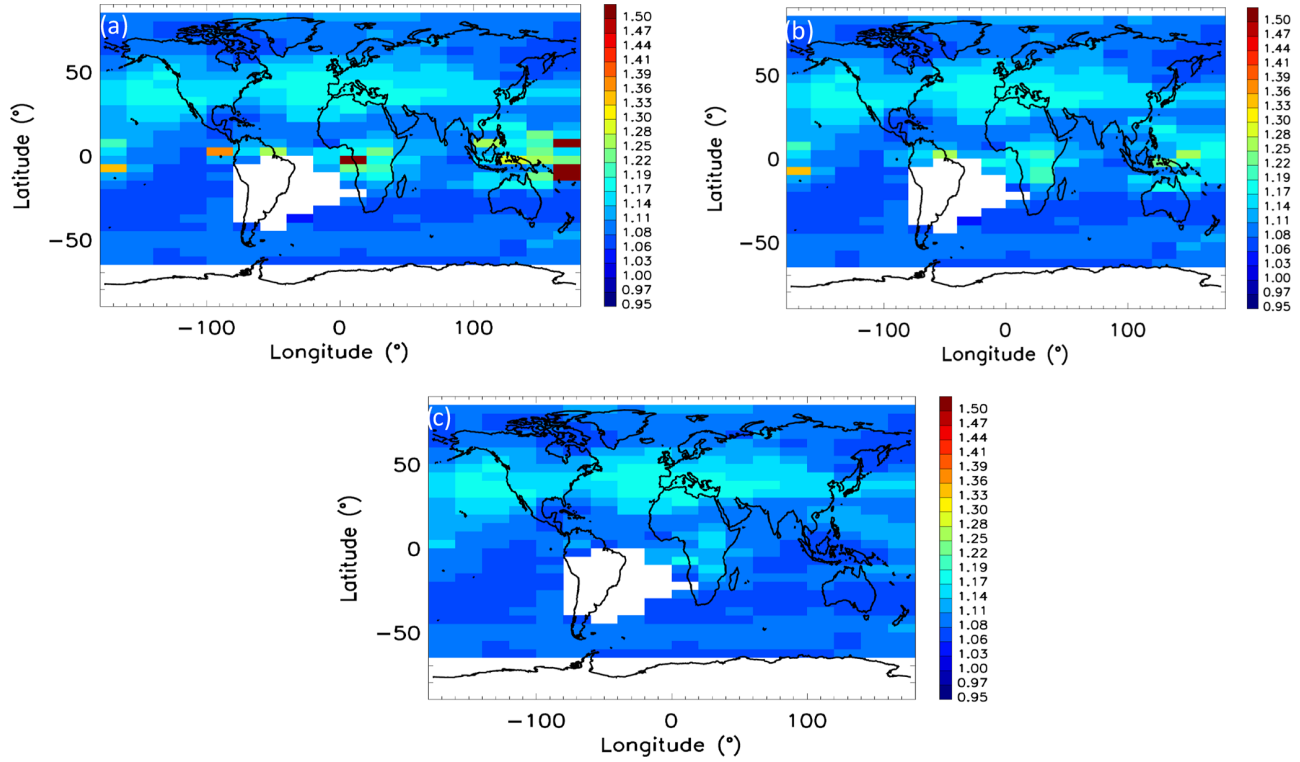

Figure 4. Attenuated scattering ratios at $17 \mathrm{~km}$ in December 2011, (a) including all detected aerosol layers but before applying any filter to remove the thin cirrus clouds, (b) including all detected aerosol layers after applying the filter in the attenuated color ratio (the all-aerosol mode), and (c) excluding the detected layers and after applying the filter in the volume depolarization ratio (the background mode).

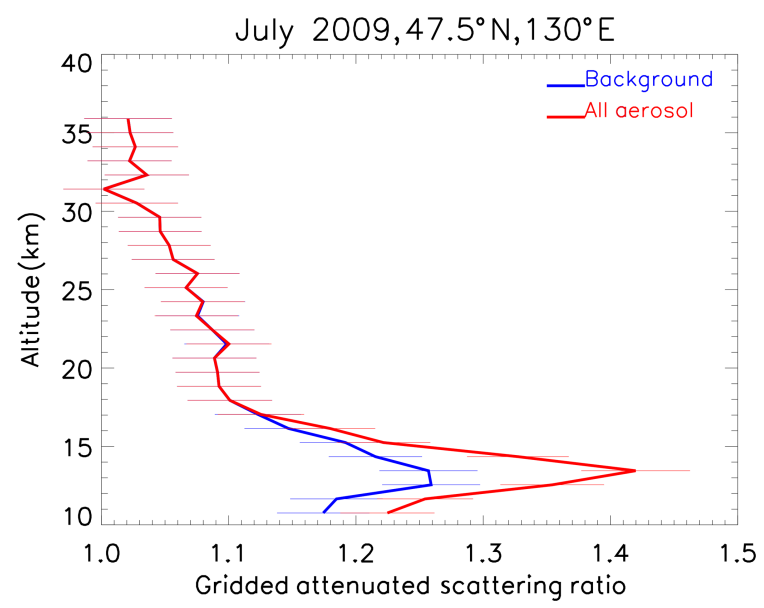

Figure 5. Profiles of attenuated scattering ratio at $47.5^{\circ} \mathrm{N}$ and $130^{\circ} \mathrm{E}$ in July 2009 for the background (blue) and all-aerosol (red) components. The error bars represent computed uncertainties.

the signatures of various stratospheric aerosol events as captured by the product and then making quantitative comparisons with observations from SAGE III on ISS.

\subsection{Signatures of stratospheric events and dynamics}

\subsubsection{Effects of volcanic and smoke injections}

Volcanoes are one of the primary sources of stratospheric aerosols (e.g., Kremser et al., 2016). Ground-based lidar studies have indicated a positive trend in stratospheric sulfate aerosol loading since the turn of the century, which was ini- tially attributed to anthropogenic emissions of $\mathrm{SO}_{2}$ from coal burning in southeast Asia (Hofmann et al., 2009). However, closer scrutiny suggests that the increase is instead related to emissions of $\mathrm{SO}_{2}$ from a large number of moderate volcanic eruptions, as was subsequently suggested by Vernier et al. (2011a) based on analyses of CALIPSO data. Several volcanoes with stratospheric impacts have been recorded since the study by Vernier et al. (2011a). Volcanic signatures in CALIPSO data were examined more recently by Friberg et al. (2018).

Figure 7 shows the time-altitude cross section of the zonally averaged extinction in the middle to high northern latitudes $\left(40-60^{\circ} \mathrm{N}\right)$, the tropics $\left(25^{\circ} \mathrm{N}-25^{\circ} \mathrm{S}\right)$, and the middle to high southern latitudes $\left(40-60^{\circ} \mathrm{S}\right)$ from the CALIPSO level 3 stratospheric aerosol product between January 2007 and December 2017. The signatures of many volcanoes are clearly evident in this figure in all three latitude bands. The strongest extinctions are seen for Sarychev and Nabro in the Northern Hemisphere and Calbuco in the Southern Hemisphere. Note that the effects of some of the volcanoes can last for several months as they spread to other latitudes by isentropic transport.

Apart from volcanic material, smoke from strong biomass burning events can also reach the stratosphere during socalled pyrocumulonimbus events (Fromm et al., 2010; Peterson et al., 2018). During the "Black Saturday" event, smoke from strong bushfires in Victoria, Australia, on 7 February 2009 is known to have impacted the stratosphere. Plumes from this blaze eventually reached altitudes of $16-20 \mathrm{~km}$ and were readily visible in satellite imagery (de Laat et al., 2012; Glatthor et al., 2013). The signature of this event can also be 
July 2009, 17 km
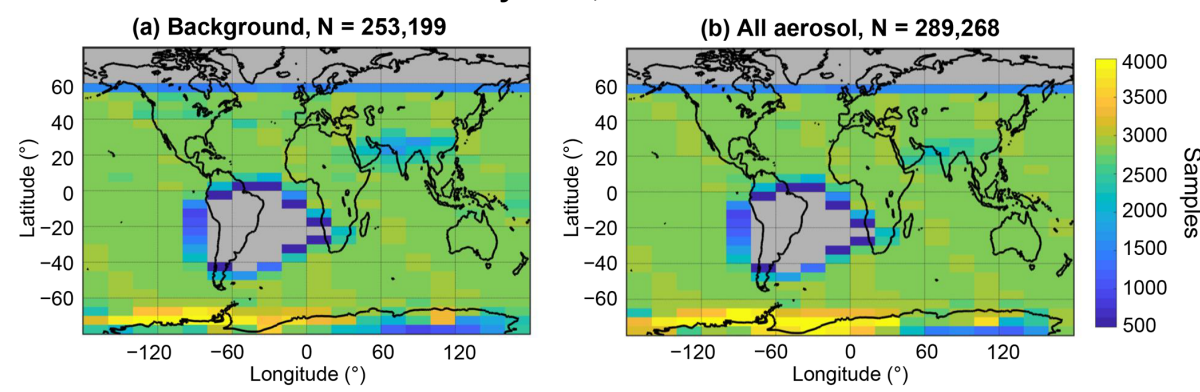

c) All aerosol minus background

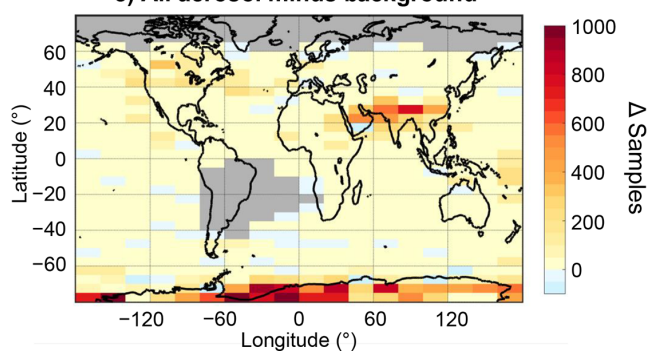

Figure 6. Number of samples contributing to (a) the background mode and (b) all-aerosol mode and (c) the difference between the two modes at $17 \mathrm{~km}$ in July 2009 . Grid cells with $<50$ samples are plotted in grey.
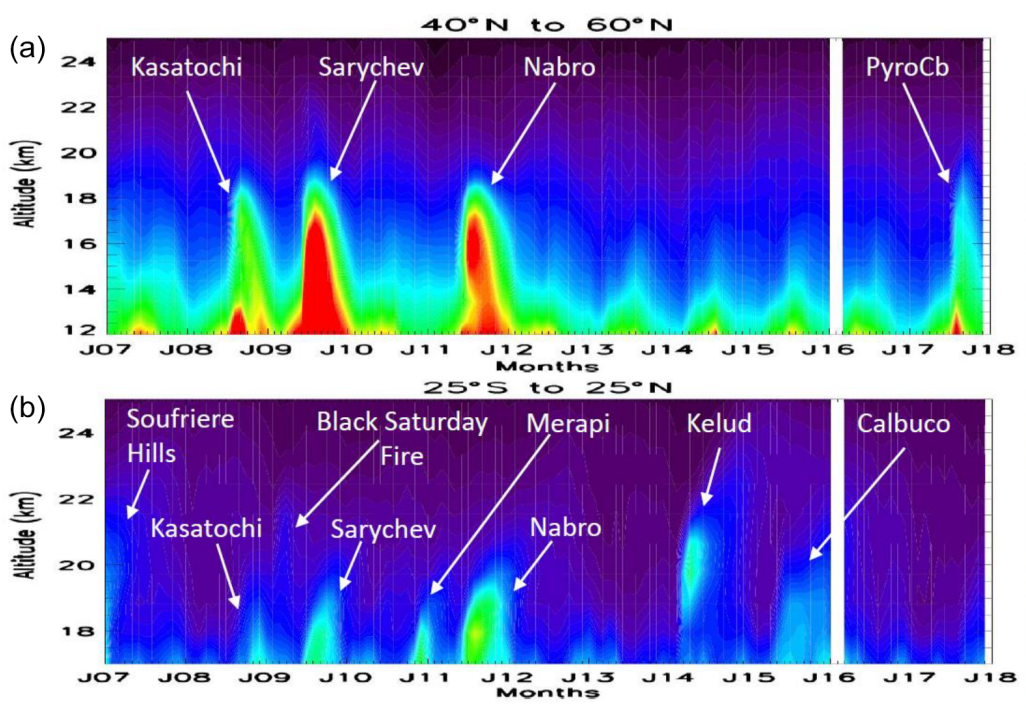

0.0020

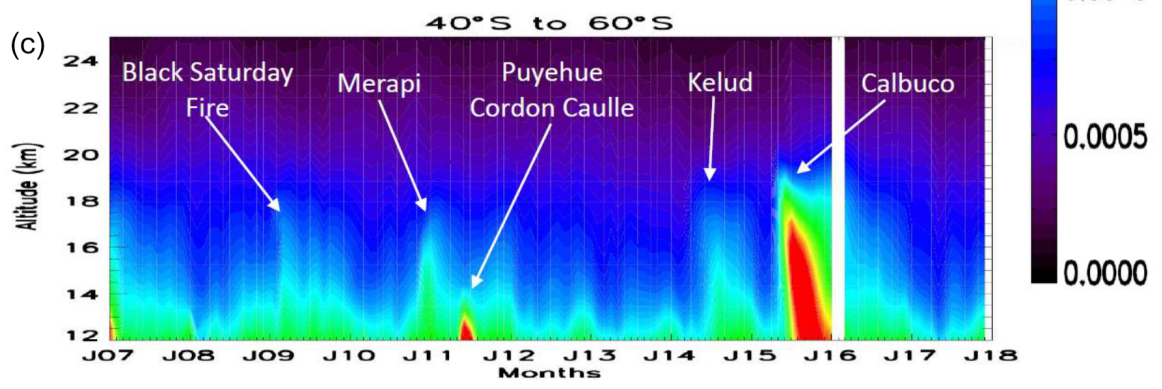

Figure 7. Time-altitude cross sections of the retrieved extinction coefficients in the all-aerosol mode from January 2007 through December 2017 for (a) the middle to high northern latitudes, (b) the tropics, and (c) the middle to high southern latitudes. The white areas indicate missing data. Note that in panel (b) for the tropics, the altitude ranges from 17 to $25 \mathrm{~km}$, whereas the range is 12 to $25 \mathrm{~km}$ in panels (a, c). 
identified in Fig. $7 b$, reaching up to nearly $22 \mathrm{~km}$. The signature of another strong pyroCb event can be seen at northern middle to high latitudes (top panel) in August-September, 2017. This event is discussed in detail below. Note the seasonal pattern of high extinction near $12-15 \mathrm{~km}$ in the northern middle- to high-latitude summer, seen most clearly between 2012 and 2017. The reason for this is not entirely clear at this time but could again be due to fire events. Cirrus cloud contamination could be another factor. However, the same pattern is also seen in the background mode (not shown) to a slightly lesser degree, which suggests that cloud contamination may not be very significant.

The extreme pyroCb event that occurred in August 2017 over British Columbia in Canada has been extensively studied recently and has been likened to volcanic perturbations in the stratosphere in terms of intensity and duration (Khaykin et al., 2018; Ansmann et al., 2018; Haarig et al., 2018; Peterson et al., 2018). Figure 8 shows an example of the CALIPSO measurements of this pyroCb event. The signature of the smoke plume is seen as extremely high attenuated backscatter (opaque at $532 \mathrm{~nm}$ ) between 60 and $65^{\circ} \mathrm{N}$. The very high attenuated color ratio $(\sim 1.6)$ seen at the base of the plume (Fig. 8c) is a tell-tale signature of smoke (e.g., Liu et al., 2008). The high volume depolarization ratio $(\geq 0.1)$ seen in Fig. $8 b$ is somewhat unusual for smoke and suggests the presence of irregular soot particles, mineral dust, and possibly some ice particles, with fast adiabatic lifting possibly retaining the initial irregular shapes (Haarig et al., 2018; Khaykin et al., 2018). This high color ratio combined with the unusually high depolarization ratio results in the plume being identified as a mixture of smoke and "volcanic ash" (Fig. 8d), the latter being misclassifications by the CALIOP V4 level 2 scene classifier.

Figure 9 shows the height-latitude cross sections of CALIOP attenuated scattering ratios from the stratospheric aerosol product between August 2017 and November 2017; it captures the evolution of the aforementioned pyroCb event. After the original injection of smoke in August 2017 at midlatitudes, the smoke spreads to lower latitudes as can be seen in these monthly mean spatial distributions from the level 3 stratospheric aerosol product. As in Fig. 3, the feature with a high attenuated scattering ratio near $25-30 \mathrm{~km}$ seen in all four panels is the signature of the tropical reservoir of stratospheric aerosols, maintained by a complex interplay of transport from the troposphere and stratospheric dynamics as well as microphysical processes including the BrewerDobson circulation, the quasi-biennial oscillation (QBO), evaporation, and sedimentation (Trepte and Hitchman, 1992; Kremser et al., 2016).

\subsubsection{Signatures of stratospheric dynamics}

Figure 10 shows the height-latitude cross section of the retrieved $532 \mathrm{~nm}$ extinction coefficients for the all-aerosol mode from March to December 2014, which captures the evolution of the Kelud eruption (February $2014 ; 7.9^{\circ} \mathrm{S}$, $112.3^{\circ} \mathrm{E}$ ) in altitude. The gradual lofting of the plume, with its top rising from $\sim 21 \mathrm{~km}$ over the tropics in March to $\sim 24 \mathrm{~km}$ in the same general location several months later, shows the signature of stratospheric dynamics in the CALIPSO stratospheric aerosol product. The persistence of the stratospheric perturbation for several months is consistent with the results of Vernier et al. (2016), who found the presence of ash in the lower stratosphere 3 months after the Kelud eruption from balloon observations. Note the high extinction values near $50-60^{\circ} \mathrm{N}$ in the lower stratosphere $(\sim 10$ $15 \mathrm{~km})$. These are similar to the summer rise in extinctions at these latitudes as discussed earlier (Fig. 7) and are possibly due to biomass burning effects but could also be related to possible cloud clearance issues. As also mentioned above, the high extinctions at high southern latitudes could be related to scattering from particles below the PSC detection threshold as well as to transported volcanic material from Kelud.

Figure 11 shows the spatial distribution of the retrieved extinction coefficients at $17 \mathrm{~km}$ for the month of August 2015 for the all-aerosol mode. Two strong perturbations of the lower stratosphere can be seen in this plot. The first is the plume from the Calbuco volcano in Chile, which erupted in April 2015. The initial plumes would be missed in the level 3 stratospheric aerosol product because data over the SAA region were not included. However, the plumes quickly spread around the Southern Hemisphere in a belt between 60 to $30^{\circ} \mathrm{S}$ (Lopes et al., 2019) and can be seen in the level 3 stratospheric aerosol product from May 2015 onwards for several months. The other is the plume of high extinction over southeast Asia and extending to the Arabian peninsula to the west. This is the location of the Asian summer monsoon anticyclone, which has been known to be a reservoir of pollution during the monsoon months and results from the deep convective outflow of pollutants, including both gases and aerosols as well as their precursors from the surface layers (Kar et al., 2004; Vernier et al., 2011b).

\subsection{Comparison with SAGE III on ISS}

In this section we provide an initial quantitative assessment of the CALIPSO level 3 stratospheric aerosol product by intercomparison of the retrieved extinction coefficients with those from the SAGE III instrument aboard the ISS (SAGE III-ISS). The SAGE III instrument on ISS was launched in February 2017 and has been providing measurements of ozone, $\mathrm{NO}_{2}$, water vapor, and aerosols from its mount on the exterior of the ISS since March 2017 (Cisewski et al., 2014). The instrument derives its legacy from the long line of SAGE instruments, which have been providing the most accurate retrievals of aerosol extinction in the stratosphere since 1984 (Chu et al., 1989; Thomason et al., 2008, 2010; Damadeo et al., 2013). SAGE III performs solar and lunar occultation measurements as the ISS orbits the Earth and covers a broad 

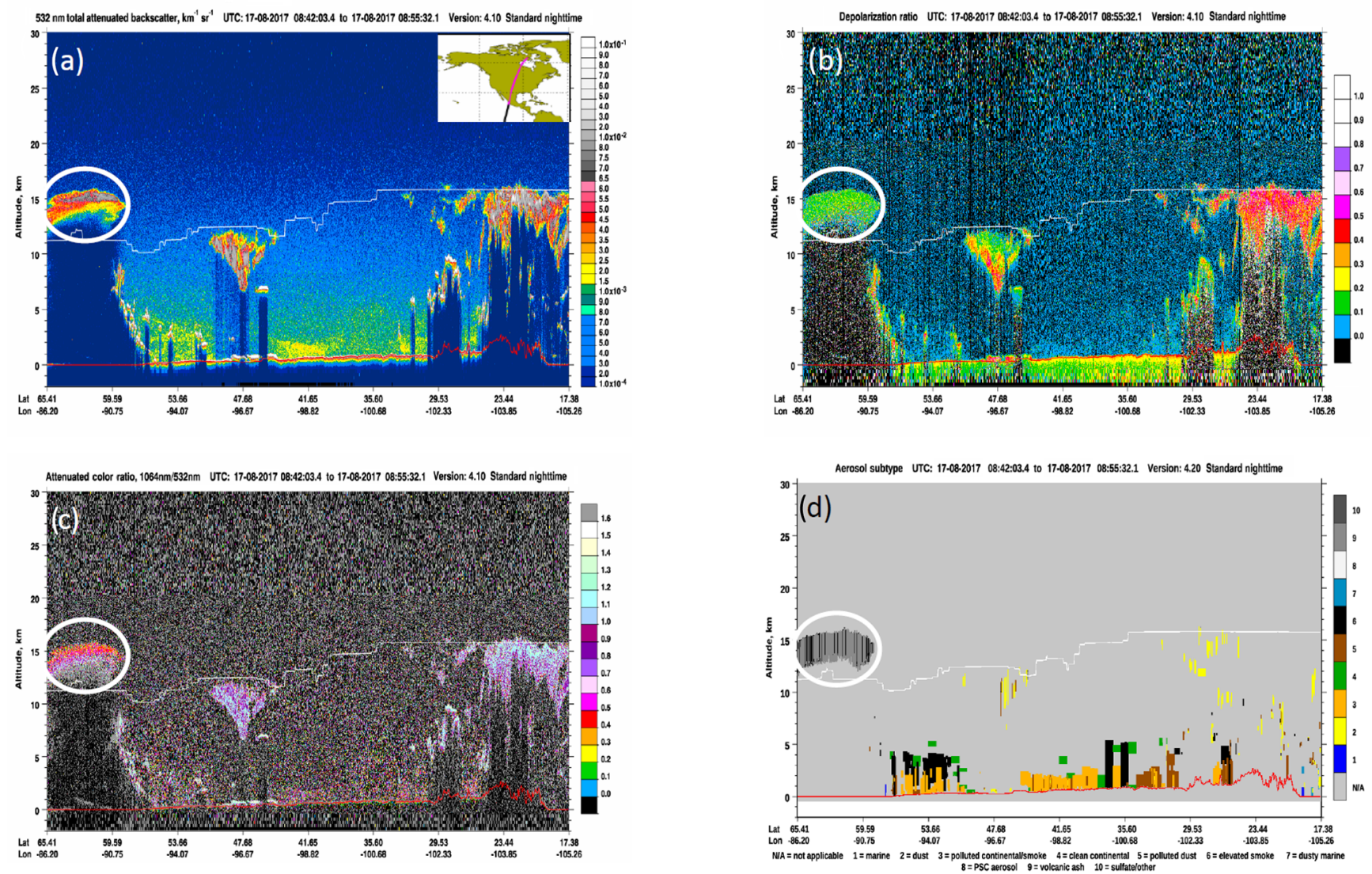

Figure 8. CALIPSO browse images of (a) $532 \mathrm{~nm}$ total attenuated backscatter, (b) $532 \mathrm{~nm}$ volume depolarization ratio, (c) attenuated backscatter color ratio $(1064 \mathrm{~nm} / 532 \mathrm{~nm})$, and (d) aerosol subtypes for a pyroCb event over Canada on 17 August 2017. The smoke plume is shown in the white circles. The white lines indicate the MERRA-2 tropopause altitude.

latitude band $\left(60^{\circ} \mathrm{S}\right.$ to $\left.60^{\circ} \mathrm{N}\right)$ and longitude range $\left(180^{\circ} \mathrm{W}\right.$ to $180^{\circ} \mathrm{E}$ ). The aerosol extinction profiles are available from the solar occultation measurements in nine channels from 384 to $1544 \mathrm{~nm}$ starting in June 2017. We use the latest version 5.1 extinction profiles reported in the $521 \mathrm{~nm}$ channel, which is closest to the CALIPSO $532 \mathrm{~nm}$ channel. In order to compare with the CALIPSO level 3 product, which reports gridded monthly averages, we average the daily data from SAGE III onto the same latitude grid (zonally averaged) as CALIPSO over a month and interpolate to the CALIPSO altitude grid. Data from both the sunrise and sunset occultations are used in the comparisons. Further, the data were filtered for cloud contamination by selecting only those data having a 521 to $1022 \mathrm{~nm}$ extinction ratio greater than 2 (Thomason and Vernier, 2013). We convert the SAGE III-ISS data at 521 to $532 \mathrm{~nm}$ by using an Ångström exponent (binned into $5^{\circ}$ latitude bins and interpolated to the CALIPSO altitude grid) derived from the extinctions retrieved at 521 and $1022 \mathrm{~nm}$ by SAGE III for the same month. Measurements from both instruments from June 2017 through August 2018 were used for this comparison. The globally averaged value of the Ångström exponent (between 521 and $1022 \mathrm{~nm}$ ) de- rived using all 15 months of data is $\sim 1.56$, essentially the same as the constant value used by Khaykin et al. (2017) to convert SAGE II extinctions at 525 to $532 \mathrm{~nm}$. We used only extinction values with a corresponding fractional extinction uncertainty less than $100 \%$ for retrievals from both instruments and calculate the differences between CALIPSO and SAGE III from the following equation:

$\Delta(z)=100 \times\left(\sigma(z)_{\text {CALIPSO }}-\sigma(z)_{\mathrm{SAGE}}\right) / \sigma(z)_{\mathrm{SAGE}}$,

where $\sigma(z)_{\text {CALIPSO }}$ is the extinction coefficient at altitude $z$ from CALIPSO, and $\sigma(z)_{\mathrm{SAGE}}$ is the extinction coefficient from SAGE III at the same altitude. Further, we use zonally averaged (into $5^{\circ}$ latitude bins) profiles for heightresolved comparisons and only the all-aerosol mode from the CALIPSO product for the sake of compatibility.

Figure 12a shows zonally averaged mean profiles of extinction coefficients retrieved from CALIPSO (in blue) and SAGE III (in red) at four latitude bands using the same 15 months of measurements from the two instruments. Figure $12 \mathrm{~b}$ shows the profiles of the fractional differences in the same latitude bands. The profiles for $0-30^{\circ} \mathrm{S}$ and 0 $30^{\circ} \mathrm{N}$ generally show fairly good agreement, with the av- 

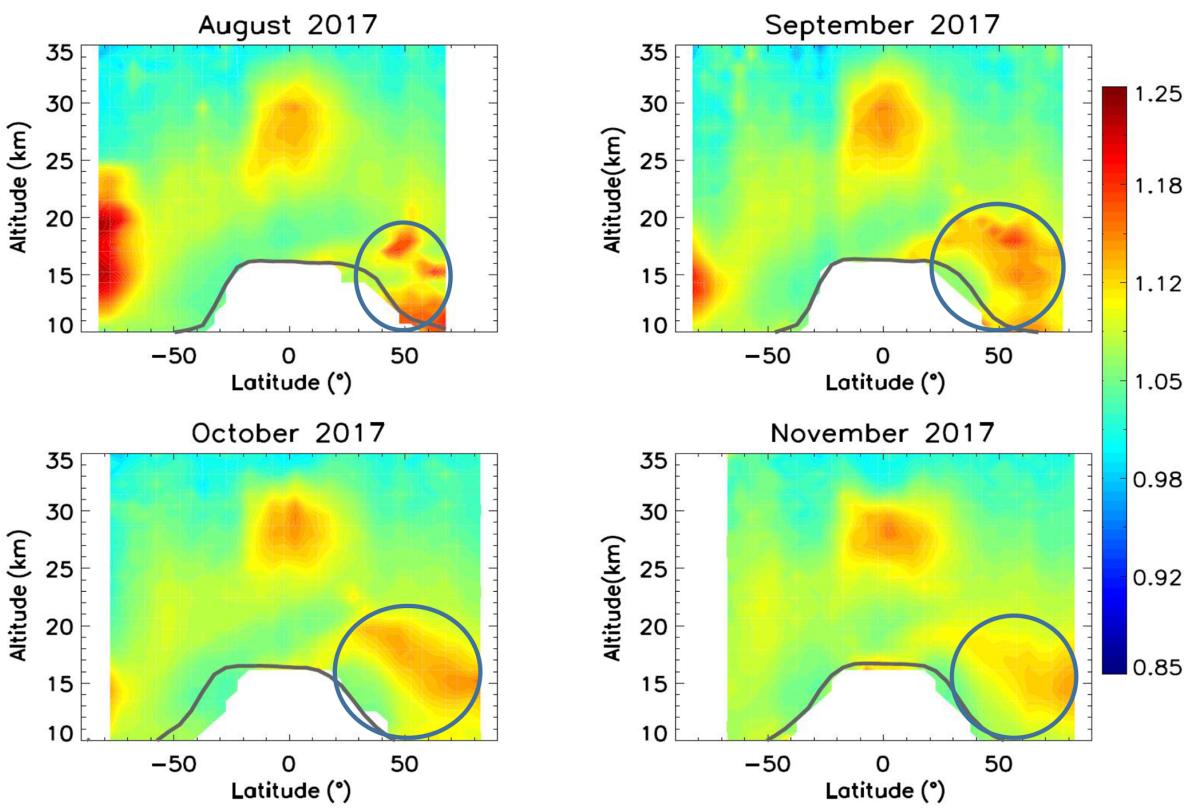

Figure 9. Zonally averaged height-latitude cross section of the $532 \mathrm{~nm}$ attenuated scattering ratios from August 2017 through November 2017. The white areas in the northern high latitudes in August and the southern high latitudes in November indicate the lack of nighttime data due to continually changing day-night terminator times.
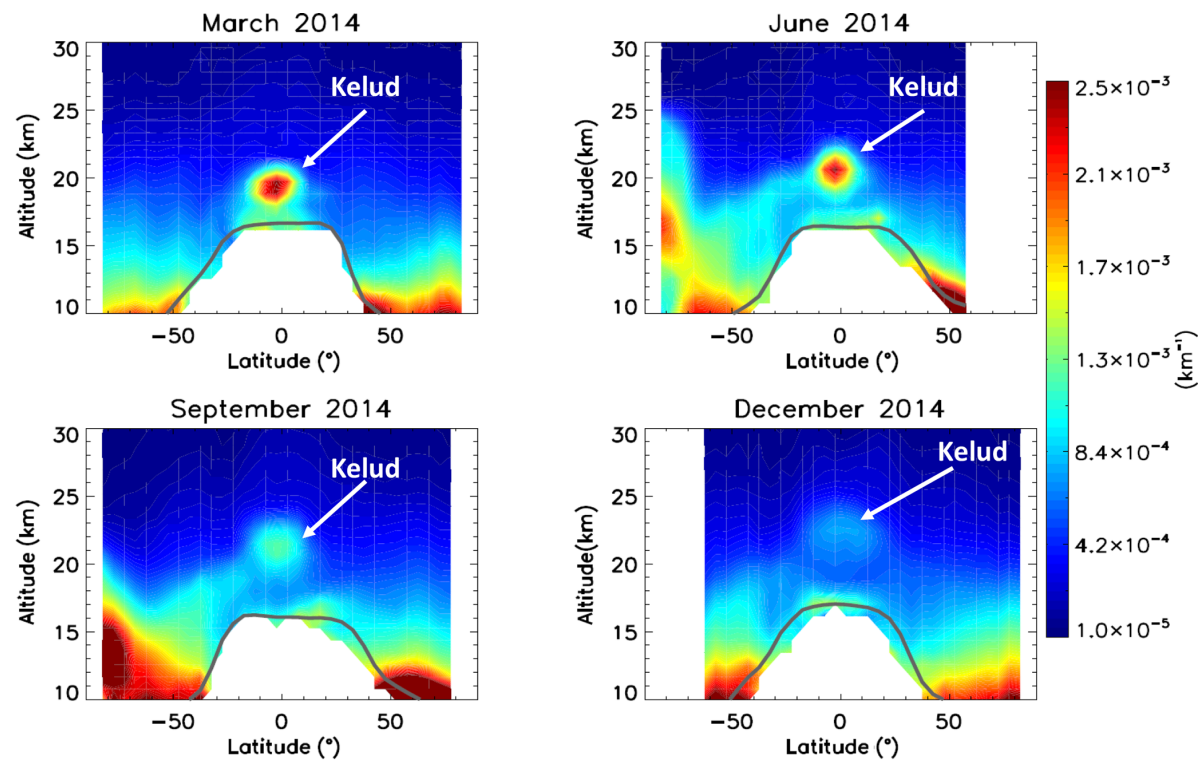

Figure 10. Zonally averaged height-latitude cross sections of $532 \mathrm{~nm}$ extinction coefficients $\left(\mathrm{km}^{-1}\right)$ in March, June, September, and December 2014. The white area in the northern high latitudes in June and in the southern high latitudes in December indicates a lack of nighttime data.

erage difference within about $25 \%$ between 20 and $30 \mathrm{~km}$. The comparisons for $30-60^{\circ} \mathrm{S}$ and $30-60^{\circ} \mathrm{N}$ are similar and both show significant differences between CALIPSO and SAGE III extinction, with CALIPSO having a high bias of less than $50 \%$ near $20 \mathrm{~km}$ increasing to $\sim 120 \%$ around $28 \mathrm{~km}$. All the profiles diverge significantly at altitudes below $20 \mathrm{~km}$, with the average difference often exceeding $100 \%$ and CALIPSO consistently overestimating SAGE III. It is likely that cloud removal artifacts in both the instruments are affecting these lower stratospheric comparisons. As pointed out in Sect. 2.2.1, the filtering scheme that removes thin cirrus clouds in the all-aerosol mode is not as efficient as the technique employed in the background mode. Consequently, scattering artifacts from undetected subvisible cir- 


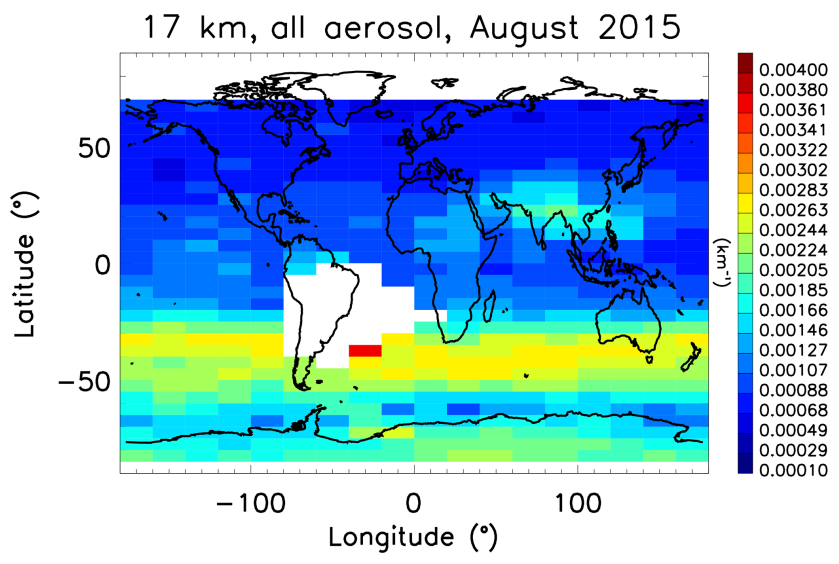

Figure 11. Retrieved $532 \mathrm{~nm}$ extinction coefficients $\left(\mathrm{km}^{-1}\right)$ at $17 \mathrm{~km}$ for August 2015.

rus are more likely to appear in the all-aerosol mode in the tropical lower stratosphere within a few kilometers above the tropopause. Using the extinction profiles from the background mode reduces the differences at these altitudes but does not completely eliminate them (not shown). Also, note that the aerosol retrievals from SAGE III (as for the legacy retrievals from SAGE II) are not directly filtered for the presence of clouds, which may impact the retrievals in the lower stratosphere. Thomason and Vernier (2013) discuss the difficulties involved in cloud identification and clearing the SAGE II measurements and conclude that it is not always possible to completely eliminate cloud contamination in the aerosol extinction retrievals. Following their recommendations, we have attempted to remove the cloud contamination in the extinction retrievals by using only those data for which the ratio of extinctions at 521 and $1022 \mathrm{~nm}$ is greater than 2. SAGE III aerosol extinctions have not been validated as of now, and it is not clear if there are any issues with the retrievals at lower altitudes near the tropopause. We further discuss the possible issues resulting from uncertainties in lidar ratios below.

Figure 13 shows the difference in the stratospheric optical depths between CALIPSO and SAGE III, calculated using the average extinction coefficient profiles between 20 and $30 \mathrm{~km}$. This region is not likely to be significantly affected by clouds and is also the region where most of the stratospheric aerosol resides; thus, comparisons here are likely to be indicative of the overall performance differences between the two sensors. Between $30^{\circ} \mathrm{S}$ and $30^{\circ} \mathrm{N}$ the optical depths are in agreement to within about $10 \%-20 \%$, though the differences begin to rise substantially in the midlatitudes of both hemispheres. (a)
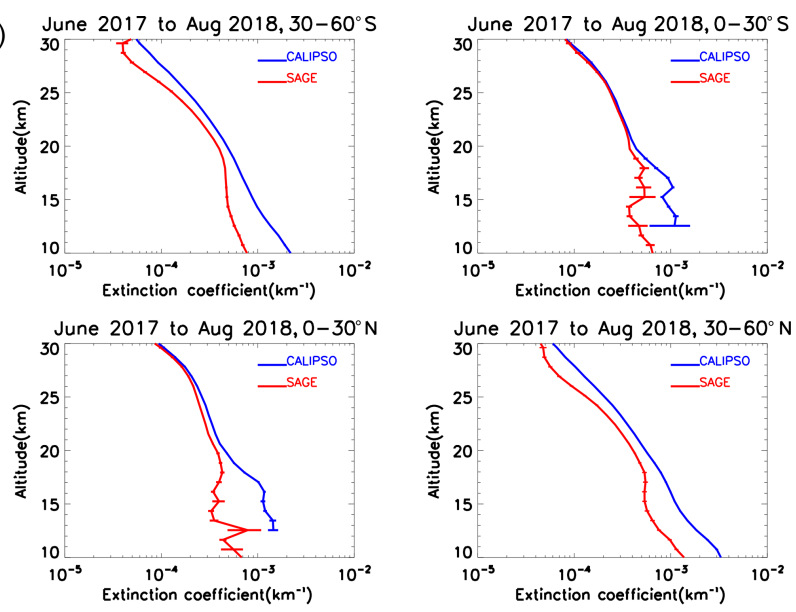

(b)

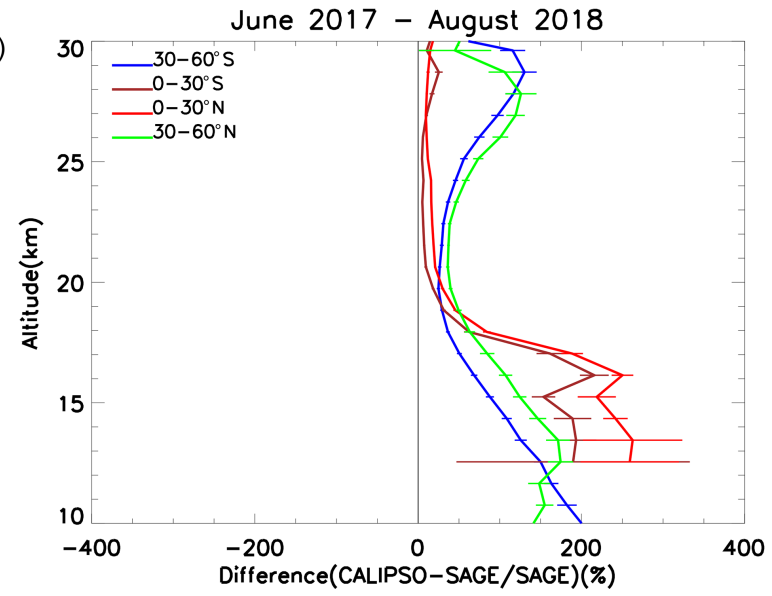

Figure 12. (a) Altitude-resolved profiles of the mean $532 \mathrm{~nm}$ extinction coefficients retrieved from CALIPSO and SAGE III using all available data between June 2017 and August 2018. The corresponding average differences are shown in panel (b). The differences are calculated at each latitude and altitude grid for each month, and then the average is taken over all the available months. The error bars represent the standard errors of the mean.

\section{Discussion}

For an initial assessment of the CALIPSO stratospheric aerosol product, we have used the aerosol retrievals from SAGE III acquired between June 2017 and August 2018. The solar occultation technique used for SAGE III retrievals does not rely on any assumptions on aerosol species or size distribution. Further, the retrieval wavelengths from SAGE III $(521 \mathrm{~nm})$ and CALIPSO $(532 \mathrm{~nm})$ are quite close, and thus the comparison of the extinction retrievals will not be significantly impacted by errors in the Ångström exponent. The previous section demonstrated that the retrieved aerosol extinction coefficients reported by the CALIPSO level 3 stratospheric aerosol product agree well with those reported by SAGE III between 20 and $30 \mathrm{~km}$ within tropical latitudes $\left(30^{\circ} \mathrm{S}-30^{\circ} \mathrm{N}\right)$, though the disparities between the two sets of 


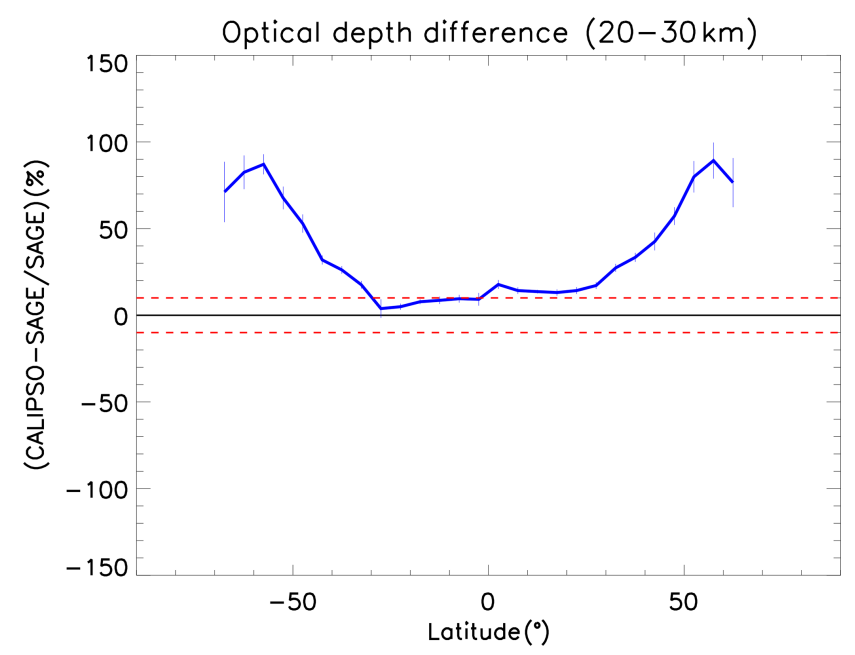

Figure 13. Fractional difference in $532 \mathrm{~nm}$ optical depth between CALIPSO and SAGE III calculated using extinction coefficients from 20 to $30 \mathrm{~km}$ as a function of latitude. The dashed red lines demarcate the $\pm 10 \%$ difference levels. The error bars represent the standard error of the mean.

measurements are significantly larger at higher latitudes and lower altitudes. The primary parameter affecting the comparison with SAGE III is likely to be the lidar ratio used in the CALIPSO retrieval. The CALIPSO extinction retrievals are quite sensitive to the lidar ratio used in the retrieval algorithm (Young et al., 2013, 2016), and the lidar ratio depends upon the optical and physical properties of the scattering particles. In the troposphere, a lookup table of lidar ratios is used by the CALIPSO extinction retrievals for various types of aerosols that might be encountered (Omar et al., 2009; Kim et al., 2018). The version 1.00 level 3 stratospheric aerosol product uses a constant lidar ratio of $50 \mathrm{sr}$ at all latitudes and altitudes for stratospheric aerosol retrievals. While a lidar ratio of $50 \mathrm{sr}$ has frequently been adopted for stratospheric analyses (e.g., Trickl et al., 2013; Ridley et al., 2014; Sakai et al., 2016; Khaykin et al., 2017), it is not clear if this value is valid for the entire stratosphere.

The adopted lidar ratio for the CALIOP stratospheric aerosol retrievals can be assessed by using the independent extinction retrievals from SAGE III and the attenuated backscatter measurements from CALIOP. For this we rewrite Eq. (3c) as

$T_{\mathrm{p}}^{2}(z)=\exp \left(-2 \int_{0}^{z} \sigma_{\mathrm{p}}\left(r^{\prime}\right) \mathrm{d} r^{\prime}\right)$

where $\sigma_{\mathrm{p}}$ is the particulate extinction coefficient as retrieved from the occultation measurements from SAGE III. Using these two-way transmittances from aerosols and computing all other terms in Eqs. (2) and (3) from CALIOP data as earlier, we can obtain an estimate of the particulate backscatter $\beta_{\mathrm{p}}(z)$. The altitude-dependent lidar ratio $S_{\mathrm{p}}(z)$ may then be obtained from the expression

$S_{\mathrm{p}}(z)=\sigma_{\mathrm{p}}(z) / \beta_{\mathrm{p}}(z)$.

Figure 14 shows the height-latitude cross section of the estimated lidar ratios from the SAGE III-ISS and CALIOP measurements. For this figure, we have used data from both the instruments from June 2017 through March 2018, excluding data from August 2017 through November 2017 to avoid the effect of smoke from the strong pyroCb event of August-September 2017 as discussed above. The data from both instruments beyond March 2018 were not used to avoid the impact of the Ambae volcano, which erupted in April 2018. As for the comparisons presented in Sect. 3, we have averaged the SAGE III-ISS data over each month, interpolated to the CALIPSO altitude grid, and computed the lidar ratios, which were then averaged to obtain the climatological distribution shown in Fig. 14. As before, we have cloudcleared the SAGE III-ISS data below $20 \mathrm{~km}$ by using only those $521 \mathrm{~nm}$ extinction coefficients for which the 521 to $1022 \mathrm{~nm}$ extinction ratio exceeded 2. The Ångström exponent obtained from these two wavelengths was used to scale the SAGE III extinction at 521 to $532 \mathrm{~nm}$. As can be seen, the lidar ratio values in the bulk of the stratosphere with significant aerosol loading are in the range $45-50 \mathrm{sr}$, quite similar to the canonical range in the stratosphere (Kremser et al., 2016), with the mean value between 18 and $30 \mathrm{~km}$ and between $40^{\circ} \mathrm{S}$ and $40^{\circ} \mathrm{N}$ being $46 \pm 6 \mathrm{sr}$. However, in the lowermost stratosphere at all latitudes and in both the polar regions at essentially all altitudes, the estimated lidar ratio values are substantially lower ( $\leq 40 \mathrm{sr}$; Fig. 14). There may be several issues impacting these estimated lidar ratios. We have used the $521 \mathrm{~nm}$ aerosol extinction product from SAGE III, which is still an evolving product. In particular, any errors in the ozone retrievals from SAGE III are likely to adversely affect the $521 \mathrm{~nm}$ aerosol extinction retrievals. Further, in the lowermost stratosphere above the tropopause, mixtures of clouds and aerosols may exist, and SAGE III aerosol data have not been cleared for clouds as such. We have used a simple cloud clearing procedure using the ratio of extinctions at 521 and $1022 \mathrm{~nm}$, which might be of limited validity near the tropopause. As mentioned above, incomplete thin cirrus removal artifacts in the CALIPSO stratospheric product, particularly in the all-aerosol mode, may also impact the estimates in the lower stratosphere within a few kilometers above the tropopause, particularly in the tropics. Similarly, at high altitudes in the polar regions the aerosol loading is expected to be quite small (extinction $\sim 10^{-5} \mathrm{~km}^{-1}$ ) and both sensors are likely to experience difficulty in retrieving these very low extinction coefficients. In particular, CALIOP can have significantly enhanced noise at those altitudes in the polar regions (see, e.g., Fig. 16 in Hunt et al., 2009), which may contribute to the differences. Also note that a lidar ratio that is in error at the highest altitudes would lead to incorrect extinction retrievals for CALIOP lower down, since the attenuation correction that is propagated downward would also be 


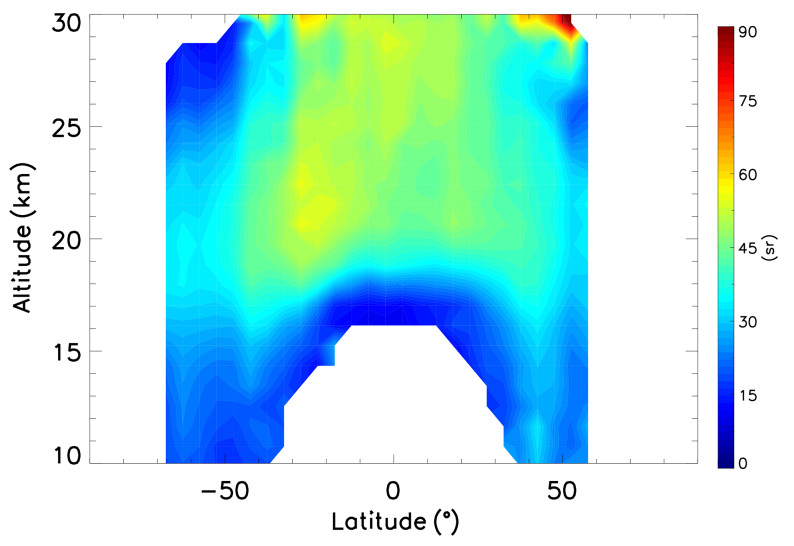

Figure 14. Spatial distribution of the stratospheric aerosol $532 \mathrm{~nm}$ lidar ratio obtained from the extinction retrievals from SAGE III and backscatter measurements from CALIOP.

in error. In any case, using a lower lidar ratio in these areas, as suggested by Fig. 14, will lead to lower retrieved extinction coefficients from CALIOP and will alleviate the differences noted in Sect. 3.

Is there any evidence of low lidar ratios in the high-latitude stratosphere as seen in Fig. 14? O'Neill et al. (2012) studied aerosol plumes from the Sarychev volcano from high Arctic observations from the Polar Environmental Atmospheric Research Laboratory (PEARL) station $\left(80.05^{\circ} \mathrm{N}\right.$, $86.42^{\circ} \mathrm{W}$ ) and estimated a characteristic lidar ratio of $59 \mathrm{sr}$ using AERONET measurements. The Arctic High Spectral Resolution Lidar (AHSRL) also retrieved lidar ratio estimates ranging between 51 and $59 \mathrm{sr}$ from measurements acquired between 10 and $15 \mathrm{~km}$. Similarly, Kravitz et al. (2011) reported lidar ratios of 50 and $60 \mathrm{sr}$ for Sarychev plumes obtained from the Koldewey Aerosol Raman Lidar (KARL) at Ny-Ålesund, Svalbard $\left(78.9^{\circ} \mathrm{N}, 11.9^{\circ} \mathrm{W}\right)$. Hoffmann et al. (2010) estimated a somewhat higher value of $65 \mathrm{sr}$ for a Kasatochi aerosol plume near the tropopause over $\mathrm{Ny}$ Ålesund in September 2008. Interestingly, and in stark contrast, for a clear day with no Kasatochi layers present, they obtained a background lidar ratio of $18 \pm 6 \mathrm{sr}$; however, more measurements are clearly needed at all stratospheric altitudes. There is also a paucity of measurements at stratospheric altitudes over southern high-latitude regions.

In the presence of large ash and even sulfate injections from volcanoes, lidar ratios can be significantly different and can evolve with time. From the so-called "constrained" retrievals, when the lidar ratios of layers can be obtained directly from the attenuation measurements from CALIOP (Young and Vaughan, 2009), the median lidar ratio of sulfate as well as ash-dominant layers from several volcanoes has been found to be $\sim 60-69 \mathrm{sr}$ (Prata et al., 2017; Kar et al., 2018b). In constructing Fig. 14, we have not used data from either instrument for the period of possible contamination from the strong pyroCb event in 2017 or after the eruption of the Ambae volcano. We shall continue to refine the lidar ratio estimates using the methodology described here as more contemporaneous measurements from SAGE III and CALIPSO become available. In future versions of the CALIOP level 3 stratospheric aerosol product we shall attempt to use a more representative lidar ratio over all of the stratosphere.

\section{Conclusion}

In this paper we have provided a detailed account of the algorithm used to construct the recently released CALIPSO level 3 stratospheric aerosol profile product version 1.00. Further, we have given a qualitative as well as an initial quantitative assessment of the aerosol extinction retrievals. We have shown that the product captures significant stratospheric aerosol injections (e.g., from volcanic eruptions and wildfires) and clearly illustrates perturbations from stratospheric dynamics over the lifetime of the mission. Comparisons with extinction retrievals obtained from SAGE III show quite good agreement to within about $25 \%$ in the mean between 20 and $30 \mathrm{~km}$ and between about $30^{\circ} \mathrm{S}$ and $30^{\circ} \mathrm{N}$. However, the comparison consistently indicates much larger deviations, exceeding 100\%-200\% (CALIPSO higher) at middle to high latitudes $\left(30-60^{\circ} \mathrm{S}\right.$ and $\left.30-60^{\circ} \mathrm{N}\right)$ and at low altitudes $(10-20 \mathrm{~km})$. The role of the lidar ratio used for the extinction retrievals in the level 3 stratospheric aerosol product was also explored. Based on combined measurements by CALIPSO and SAGE III, the current lidar ratio of $50 \mathrm{sr}$ is shown to be appropriate for background conditions above $20 \mathrm{~km}$ in the tropics. However, it may be unrepresentative of lidar ratios closer to the tropopause and at middle to high latitudes. Future versions of the CALIPSO level 3 stratospheric aerosol profile product may refine the lidar ratios based on these and forthcoming analyses.

Data availability. CALIPSO lidar level 1B, level 2, and level 3 stratospheric aerosol data products (Vaughan et al., 2016) are available from the Atmospheric Science Data Center at NASA LaRC (https://eosweb.larc.nasa.gov/project/calipso/calipso_table, last access: 13 November 2019). The SAGE III-ISS data products (SAGE III science team, 2013) are also available at the Atmospheric Science Data Center (https://eosweb.larc.nasa.gov/project/ sageiii-iss/sageiii-iss_table, last access: 13 November 2019).

Author contributions. All authors contributed to the development of the algorithm for the CALIPSO level 3 stratospheric aerosol product, which is described in this paper. JK wrote the initial draft of the paper, and KPL, MAV, JLT, and BJG contributed through data analysis, additional figures, and augmenting the text. CRT, DMW, and PLL provided overall guidance on the structure of the paper. 
Competing interests. The authors declare that they have no conflict of interest.

Acknowledgements. Jayanta Kar would like to thank Jean-Paul Vernier, Mike Pitts, Larry Thomason, and Stuart Young for useful discussions during the development of the CALIPSO stratospheric product. SAGE III-ISS aerosol data were obtained from the Langley Atmospheric Science Data Center. The referees are thanked for useful comments and suggestions that significantly improved the paper. Jayanta Kar would like to acknowledge illuminating discussions with Mike Pitts on PSCs and Larry Thomason on SAGE III-ISS aerosol data.

Review statement. This paper was edited by Alexander Kokhanovsky and reviewed by Andrew Prata, Michael Fromm, Sergey Khaykin, and one anonymous referee.

\section{References}

Ansmann, A., Baars, H., Chudnovsky, A., Mattis, I., Veselovskii, I., Haarig, M., Seifert, P., Engelmann, R., and Wandinger, U.: Extreme levels of Canadian wildfire smoke in the stratosphere over central Europe on 21-22 August 2017, Atmos. Chem. Phys., 18, 11831-11845, https://doi.org/10.5194/acp-18-118312018, 2018.

Beyerle, G., Neuber, R., Schrems, O., Wittrock, F., and Knudsen, B.: Multiwavelength lidar measurements of stratospheric aerosols above Spitsbergen during winter 1992/93, Geophys. Res. Lett., 21, 57-60, https://doi.org/10.1029/93GL02846, 1994.

Brock, C. A., Jonsson, H. H., Wilson, J. C., Dye, J. E., Baumgardner, D., Borrmann, S., Pitts, M. C., Osborn, M. T., Decoursey, R. J., and Woods, D. C.: Relations between optical extinction, backscatter and aerosol surface and volume in the stratosphere following the eruption of Mt. Pinatubo, Geophys. Res. Lett., 20, 2555-2558 https://doi.org/10.1029/93GL01691, 1993.

Bourassa, A. E., Rieger, L. A., Lloyd, N. D., and Degenstein, D. A.: Odin-OSIRIS stratospheric aerosol data product and SAGE III intercomparison, Atmos. Chem. Phys., 12, 605-614, https://doi.org/10.5194/acp-12-605-2012, 2012.

Chazette, P., David, C., Lefrere, J., Godin, S., Pelon, J., and Megie, G.: Comparative lidar study of the optical, geometrical and dynamical properties of stratospheric postvolcanic aerosols, following the eruptions of El Chichon and Mount Pinatubo, J. Geophys. Res., 100, 23195-23207, https://doi.org/10.1029/95JD02268, 1995.

Chen, Z., Bhartia, P. K., Loughman, R., Colarco, P., and DeLand, M.: Improvement of stratospheric aerosol extinction retrieval from OMPS/LP using a new aerosol model, Atmos. Meas. Tech., 11, 6495-6509, https://doi.org/10.5194/amt-116495-2018, 2018.

Chu, W. P. and McCormick, M. P.: Inversion of stratospheric aerosol and gaseous constituents from spacecraft solar extinction data in the $0.38-1.0 \mu \mathrm{m}$ wavelength region, Appl. Optics, 18, 1404 1413,1979 .
Chu, W. P., McCormick, M. P., Lenoble, J., Brogniez, C., and Pruvost, P.: SAGE II inversion algorithm, J. Geophys. Res., 94, 8339-8351, https://doi.org/10.1029/JD094iD06p08339, 1989.

Cisewski, M., Zawodny, J., Gasbarre, J., Eckman, R., Topiwala, N., Rodriguez-Alverez, O., Cheek, D., and Hall, S.: The Stratospheric Aerosol and Gas Experiment (SAGE III) on the International Space Station (ISS) Mission, Proc. SPIE 9241, Sensors, Systems, and Next-Generation Satellites XVIII, 924107 (11 November 2014), Amsterdam, Netherlands, https://doi.org/10.1117/12.2073131, 2014.

Damadeo, R. P., Zawodny, J. M., Thomason, L. W., and Iyer, N.: SAGE version 7.0 algorithm: application to SAGE II, Atmos Meas. Tech., 6, 3539-3561, https://doi.org/10.5194/amt-6-35392013, 2013.

de Laat, A. T. J., Stein Zweers, D. C., Boers, R.. and Tuinder, O. N. E.: A solar escalator: Observational evidence of the self-lifting of smoke and aerosols by absorption of solar radiation in the February 2009 Australian Black Saturday plume, J. Geophys. Res., 117, D04204, https://doi.org/10.1029/2011JD017016, 2012.

Deshler, T.: A review of global stratospheric aerosol: Measurements, importance, life cycle, and local stratospheric aerosol, Atmos. Res., 90, 223-232, https://doi.org/10.1016/j.atmosres.2008.03.016, 2008.

Friberg, J., Martinsson, B. G., Andersson, S. M., and Sandvik, O. S.: Volcanic impact on the climate - the stratospheric aerosol load in the period 2006-2015, Atmos. Chem. Phys., 18, 11149-11169, https://doi.org/10.5194/acp-18-11149-2018, 2018.

Fromm, M., Lindsey, D. T., Servranckx, R., Yue, G., Trickl, T., Sica, R., Doucet, P., and Godin-Beekmann, S.: The untold story of pyrocumulonimbus, B. Am. Meteorol. Soc., 91, 1193-1209, https://doi.org/10.1175/2010BAMS3004.1, 2010.

Gelaro, R., McCarty, W., Suarez, M. J., Todling, R., Molod, A., Takacs, L., Randles, C. A., Darmenov, A., Bosilovich, M. G., Reichle, R., Wargan, K., Coy, L., Cullather, R., Draper, C., Akella, S., Buchard, V., Conaty, A., Da Silva, A. M., Gu, W., Kim, G.K., Koster, R., Lucchesi, R., Markova, D., Nielsen, J. E., Partyka, G., Pawson, S., Putman, W., Rienecker, M., Schubert, S. C., Sienkiewicz, M., and Zhao, B.: The Modern-Era Retrospective Analysis for Research and Applications, Version 2 (MERRA-2), J. Climate, 30, 5419-5454, https://doi.org/10.1175/JCLI-D-160758.1, 2017.

Glaccum, W., Lucke, R. L., Bevilacqua, R. M., Shettle, E. P., Hornstein, J. S., Chen, D. T., Lumpe, J. D., Hrigman, S. S., Debrestian, J. J., Fromm, M. D., Dalaudier, F., Chassefiere, F., Deniel, C., Randall, C. E., Rusch, D. W., Olivero, J. J., Brogniez, C., Lenoble, J., and Kremer, R.: The polar ozone and aerosol measurement instrument, J. Geophys. Res., 101, 14479-14487, 1996.

Glatthor, N., Höpfner, M., Semeniuk, K., Lupu, A., Palmer, P. I., McConnell, J. C., Kaminski, J. W., von Clarmann, T., Stiller, G. P., Funke, B., Kellmann, S., Linden, A., and Wiegele, A.: The Australian bushfires of February 2009: MIPAS observations and GEM-AQ model results, Atmos. Chem. Phys., 13, 1637-1658, https://doi.org/10.5194/acp-13-1637-2013, 2013.

Grams, G. and Fiocco, G.: Stratospheric aerosol layer during 1964 and 1965, J. Geophys. Res., 72, 3523-3542, https://doi.org/10.1029/JZ072i014p03523, 1967.

Haarig, M., Ansmann, A., Baars, H., Jimenez, C., Veselovskii, I., Engelmann, R., and Althausen, D.: Depolarization and lidar ratios at 355, 532, and $1064 \mathrm{~nm}$ and microphysi- 
cal properties of aged tropospheric and stratospheric Canadian wildfire smoke, Atmos. Chem. Phys., 18, 11847-11861, https://doi.org/10.5194/acp-18-11847-2018, 2018.

Hofmann, D. J., Rosen, J. M., Pepin, T. J., and Pinninck, R. G.: Stratospheric aerosol measurements I: Time variations at northern midlatitudes, J. Atmos. Sci., 32, 1446-1456, 1975.

Hofmann, D., Barnes, J., O’Neill, M., Trudeau, M., and Neely, R.: Increase in background stratospheric aerosol observed with lidar at Mauna Loa observatory and Boulder, Colorado, Geophys. Res. Lett., 36, L15808, https://doi.org/10.1029/2009GL039008, 2009.

Hoffmann, A., Ritter, C., Stock, M., Maturilli, M., Eckhardt, S., Herber, A., and Neuber, R.: Lidar measurements of the Kasatochi aerosol plume in August and September 2008 in Ny-Ålesund, Spitsbergen, J. Geophys. Res., 115, D00L12, https://doi.org/10.1029/2009JD013039, 2010.

Hunt, W. H., Winker, D. M., Vaughan, M. A., Powell, K. A., Lucker, P. L., and Weimer, C.: CALIPSO Lidar description and performance assessment, J. Atmos. Ocean. Tech., 26, 1214-1228, https://doi.org/10.1175/2009JTECHA1223.1, 2009.

Jaeger, H. and Deshler, T.: Lidar backscatter to extinction, mass and area conversions for stratos- pheric aerosols based on midlatitude balloonborne size distribution measurements, Geophys. Res. Lett., 29, 1929, https://doi.org/10.1029/2002GL015609, 2002.

Junge, C. E. and Manson, J. E.: Stratospheric aerosol studies, J. Geophys. Res., 66, 2163-2182, https://doi.org/10.1029/JZ066i007p02163, 1961.

Kar, J., Bremer, H., Drummond, J. R., Rochon, Y. J., Jones, D. B. A., Nichitiu, F., Zou, J., Liu, J., Gille, J. C., Edwards, D. P., Deeter, M. N., Francis, G., Ziskin, D., and Warner, J.: Evidence of vertical transport of carbon monoxide from Measurements of Pollution in the Troposphere, Geophys. Res. Lett., 31, L23105, https://doi.org/10.1029/2004GL021128, 2004.

Kar, J., Vaughan, M. A., Lee, K.-P., Tackett, J. L., Avery, M. A., Garnier, A., Getzewich, B. J., Hunt, W. H., Josset, D., Liu, Z., Lucker, P. L., Magill, B., Omar, A. H., Pelon, J., Rogers, R. R., Toth, T. D., Trepte, C. R., Vernier, J.-P., Winker, D. M., and Young, S. A.: CALIPSO lidar calibration at $532 \mathrm{~nm}$ : version 4 nighttime algorithm, Atmos. Meas. Tech., 11, 1459-1479, https://doi.org/10.5194/amt-11-1459-2018, $2018 \mathrm{a}$.

Kar, J., Vaughan, M. A., Tackett, J., Omar, A., Trepte, C. R. ,and Lucker, P. L.: Constrained lidar ratios for volcanic ash and sulfate layers in the stratosphere from CALIOP version 4.10 data, American Geophysical Union Fall Meeting, Washington, DC, 10-14 December 2018b.

Kent, G. S. and McCormick, M. P.: SAGE and SAM II measurements of global stratospheric aerosol optical depth and mass loading, J. Geophys. Res., 89, 5303-5314, 1984.

Khaykin, S. M., Godin-Beekmann, S., Keckhut, P., Hauchecorne, A., Jumelet, J., Vernier, J.-P., Bourassa, A., Degenstein, D. A., Rieger, L. A., Bingen, C., Vanhellemont, F., Robert, C., DeLand, M., and Bhartia, P. K.: Variability and evolution of the midlatitude stratospheric aerosol budget from 22 years of ground-based lidar and satellite observations, Atmos. Chem. Phys., 17, 18291845, https://doi.org/10.5194/acp-17-1829-2017, 2017.

Khaykin, S. M., Godin-Beekmann, S., Hauchecorne, A., Pelon, J., Ravetta, F., and Keckhut, P.: Stratospheric smoke with unprecedentedly high backscatter observed by lidars above southern France, Geophys. Res. Lett., 45, 1639-1646, https://doi.org/10.1002/2017GL076763, 2018.
Kim, M.-H., Omar, A. H., Tackett, J. L., Vaughan, M. A., Winker, D. M., Trepte, C. R., Hu, Y., Liu, Z., Poole, L. R., Pitts, M. C., Kar, J., and Magill, B. E.: The CALIPSO version 4 automated aerosol classification and lidar ratio selection algorithm, Atmos. Meas. Tech., 11, 6107-6135, https://doi.org/10.5194/amt11-6107-2018, 2018.

Kravitz, B., Robock, A., Bourassa, A., Deshler, T., Wu, D., Mattis, I., Finger, F., Hoffmann, A., Ritter, C., Bitar, L., Duck, T. J., and Barnes, J. E.: Simulation and observations of stratospheric aerosols from the 2009 Sarychev volcanic eruption, J. Geophys. Res., 116, D18211, https://doi.org/10.1029/2010JD015501, 2011.

Kremser, S., Thomason, L. W., von Hobe, M., Hermann, M., Deshler, T., Timmreck, C., Toohey, M., Stenke, A., Schwarz, J. P., Weigel, R., Fueglistaler, S., Prata, F. J., Vernier, J.-P., Schlager, H., Barnes, J. E., Antuna-Marrero, J.-C., Fairlie, D., Palm, M., Mahieu, E., Notholt, J., Rex, M., Bingen, C., Vanhellemont, F., Bourassa, A., Plane, J. M. C., Kolcke, D., Carn, S. A., Clarisse, L., Trickl, T., Neely, R., James, A. D., Rieger, L., Wilson, J. C., and Meland, B.: Stratospheric aerosol-Observations, processes and impact on climate, Rev. Geophys., 54, 278-335, https://doi.org/10.1002/2015RG000511, 2016.

Liu, Z., Liu, D., Huang, J., Vaughan, M., Uno, I., Sugimoto, N., Kittaka, C., Trepte, C., Wang, Z., Hostetler, C., and Winker, D.: Airborne dust distributions over the Tibetan Plateau and surrounding areas derived from the first year of CALIPSO lidar observations, Atmos. Chem. Phys., 8, 5045-5060, https://doi.org/10.5194/acp8-5045-2008, 2008.

Liu, Z., Vaughan, M., Winker, D., Kittaka, C., Getzewich, B., Kuehn, R., Omar, A., Powell, K., Trepte, C., and Hostetler, C.: The CALIPSO lidar cloud and aerosol discrimination: Version 2 Algorithm and initial assessment of performance, J. Atmos. Ocean. Tech., 26, 1198-1212, https://doi.org/10.1175/2009JTECHA1229.1, 2009.

Liu, Z., Kar, J., Zeng, S., Tackett, J., Vaughan, M., Avery, M., Pelon, J., Getzewich, B., Lee, K.-P., Magill, B., Omar, A., Lucker, P., Trepte, C., and Winker, D.: Discriminating between clouds and aerosols in the CALIOP version 4.1 data products, Atmos. Meas. Tech., 12, 703-734, https://doi.org/10.5194/amt-12-7032019, 2019.

Lopes, F. J. S., Silva, J. J., Antuña Marrero, J. C., Taha, G. and Landulfo, E.: Synergetic Aerosol Layer Observation After the 2015 Calbuco Volcanic Eruption Event, Remote Sensing, 11, 195, https://doi.org/10.3390/rs11020195, 2019.

Lucke, R. L., Korwan, D. R., Bevilacqua, R. M., Hornstein, J. S., Shettle, E. P., Chen, D. T., Daehler, M., Lumpe, J. D., Fromm, M. D., Debrestian, D., Neff, B., Squire, M., König-Langlo, G., and Davies, J.: The Polar Ozone and Aerosol Measurement (POAM III) instrument and early validation results, J. Geophys. Res., 104, 18785-18799, 1999.

Mauldin III, L. E., Zaun, N. H., McCormick, M. P., Guy, J. H., and Vaughan, W. R.: Stratospheric aerosol and Gas Experiment II instruments: A functional description, Opt. Eng., 24, 307-312, https://doi.org/10.1117/12.7973473, 1985.

McCormick, M. P., Swissler, T. J., Fuller, W. H., Hunt, W. H., and Osborn, M. T.: Airborne and Ground-Based lidar measurements of the El Chichón stratospheric aerosol from $90^{\circ} \mathrm{N}$ to $56^{\circ} \mathrm{S}, \mathrm{Ge}-$ ofis. Int., 23, 187-221, 1984. 
McElroy, C. T., Nowlan, C. R., Drummond, J. R., Bernath, P. F., Barton, D. V., Dufour, D. G., Midwinter, C., Hall, R. B., Ogyu, A., Ullberg, A., Wardle, D. I., Kar, J., Zou, J., Nichitiu, F., Boone, C. D., Walker, K. A., and Rowlands, N.: The ACE-MAESTRO instrument on SCISAT: Description, performance, and preliminary results, Appl. Optics, 46, 4341-4356, 2007.

McGill, M. J., Vaughan, M. A., Trepte, C. R., Hart, W. D., Hlavka, D. L., Winker, D. M., and Kuehn, R.: Airborne validation of spatial properties measured by the CALIPSO lidar, J. Geophys. Res., 112, D20201, https://doi.org/10.1029/2007JD008768, 2007.

Noel, V., Chepfer, H., Hoareau, C., Reverdy, M., and Cesana, G.: Effects of solar activity on noise in CALIOP profiles above the South Atlantic Anomaly, Atmos. Meas. Tech., 7, 1597-1603, https://doi.org/10.5194/amt-7-1597-2014, 2014.

Northam, G. B., Rosen, J. M., Melfi, S. H., Pepin, T. J., McCormick, M. P., Hofmann, D. J., and Fuller, W. H.: Dustsonde and Lidar Measurements of Stratospheric Aerosols: a Comparison, Appl. Optics, 13, 2416-2421, https://doi.org/10.1364/AO.13.002416, 1974.

Omar, A. H., Winker, D. M., Vaughan, M. A., Hu, Y., Trepte, C. R., Ferrare, R. A., Lee, K. P., Hostetler, C. A., Kittaka, C., Rogers, R. R., and Kuehn, R. E.: The CALIPSO Automated Aerosol Classification and Lidar Ratio Selection Algorithm, J. Atmos. Ocean. Tech., 26, 1994-2014, https://doi.org/10.1175/2009JTECHA1231.1, 2009.

O’Neill, N. T., Perro, C., Saha, A., Lesins G., Duck, T. J., Eloranta, E. W., Nott, G. J., Hoffman, A., Karumudi, M. L., Ritter, C., Bourassa, A., Abboud, I., Carn, S. A., and Savastiouk, V.: Properties of Sarychev sulphate aerosols over the Arctic, J. Geophys. Res., 117, D04203, https://doi.org/10.1029/2011JD016838, 2012.

Penning de Vries, M. J. M., Dörner, S., Puīte, J., Hörmann, C., Fromm, M. D., and Wagner, T.: Characterisation of a stratospheric sulfate plume from the Nabro volcano using a combination of passive satellite measurements in nadir and limb geometry, Atmos. Chem. Phys., 14, 8149-8163, https://doi.org/10.5194/acp-14-8149-2014, 2014.

Peterson, D. A., Campbell, J. R., Hyer, E. J., Fromm, M. D., Kablick III, G. P., Cossuth, J. H., and DeLand, M. T.: Wildfiredriven thunderstorms cause a volcano-like stratospheric injection of smoke, npj Climate and Atmospheric Science, 1, 30, https://doi.org/10.1038/s41612-018-0039-3, 2018.

Pitts, M. C., Thomason, L. W., Poole, L. R., and Winker, D. M.: Characterization of Polar Stratospheric Clouds with spaceborne lidar: CALIPSO and the 2006 Antarctic season, Atmos. Chem. Phys., 7, 5207-5228, https://doi.org/10.5194/acp-7-5207-2007, 2007.

Pitts, M. C., Poole, L. R., and Thomason, L. W.: CALIPSO polar stratospheric cloud observations: second-generation detection algorithm and composition discrimination, Atmos. Chem. Phys., 9, 7577-7589, https://doi.org/10.5194/acp-9-7577-2009, 2009.

Powell, K. A.: Development of the CALIPSO Lidar Simulator, M.Sc. thesis, Department of Applied Science, The College of William and Mary, 228 pp., 2005.

Powell, K. A., Hostetler, C. A., Liu, Z., Vaughan, M. A., Kuehn, R. A., Hunt, W. H., Lee, K.-P., Trepte, C. R., Rogers, R. R., Young, S. A., and Winker, D. M.: CALIPSO Lidar calibration algorithms. Part I: Nighttime $532 \mathrm{~nm}$ parallel channel and $532 \mathrm{~nm}$ perpendicular channel, J. Atmos. Ocean. Tech., 26, 2015-2033, https://doi.org/10.1175/2009JTECHA1242.1, 2009.

Prata, A. T., Young, S. A., Siems, S. T., and Manton, M. J.: Lidar ratios of stratospheric volcanic ash and sulfate aerosols retrieved from CALIOP measurements, Atmos. Chem. Phys., 17, 85998618, https://doi.org/10.5194/acp-17-8599-2017, 2017.

Ridley, D. A., Solomon, S., Barnes, J. E., Burlakov, V. D., Deshler, T., Dolgii, S. I., Herber, A. B., Nagai, T., Neely, R. R., Nevzorov, A. V., Ritter, C., Sakai, T., Santer, B. D., Sato, M., Schmidt, A., Uchino, O., and Vernier, J. P.: Total volcanic stratospheric aerosol optical depths and implications for global climate change, Geophys. Res. Lett., 41, 7763-7769, https://doi.org/10.1002/2014GL061541, 2014.

Robock, A.: Volcanic eruptions and climate, Rev. Geophys., 38, 191-219, https://doi.org/10.1029/1998RG000054, 2000.

SAGE III Science Team: SAGE III Level 2 Data, NASA Atmospheric Science Data Center (ASDC), Hampton, VA, USA, https://doi.org/10.5067/ISS/SAGEIII/SOLAR_HDF4_L2V5.1, 2013.

Sakai, T., Uchino, O., Nagai, N., Liley, B., Morino, I., and Fujimoto, T.: Long-term variation of stratospheric aerosols observed with lidars over Tsukuba, Japan, from 1982 and Lauder, New Zealand, from 1992 to 2015, J. Geophys. Res.-Atmos., 121, 10283-10293, https://doi.org/10.1002/2016JD025132, 2016.

Sassen, K., Wang, Z., and Liu, D.: Cirrus clouds and deep convection in the tropics: Insighs from CALIPSO and CloudSat, J. Geophys. Res., 114, D00H06, https://doi.org/10.1029/2009JD011916, 2009.

Solomon, S., Daniel, J. S., Neely III, R. R., Vernier, J. P., Dutton, E. G., and Thomason, L. W.: The persistently variable "background" stratospheric aerosol layer and global climate change, Science, 333, 866-870, https://doi.org/10.1126/science.1206027, 2011.

Thomason, L. W. and Peter, T.: Assessment of stratospheric aerosol properties (ASAP), SPARC report no 4, WCRP-124,WMO/TDNo. 1295, 2006.

Thomason, L. W. and Vernier, J.-P.: Improved SAGE II cloud/aerosol categorization and observations of the Asian tropopause aerosol layer: 1989-2005, Atmos. Chem. Phys., 13, 4605-4616, https://doi.org/10.5194/acp-13-4605-2013, 2013.

Thomason, L. W., Pitts, M. C., and Winker, D. M.: CALIPSO observations of stratospheric aerosols: a preliminary assessment, Atmos. Chem. Phys., 7, 5283-5290, https://doi.org/10.5194/acp-75283-2007, 2007.

Thomason, L. W., Burton, S. P., Luo, B.-P., and Peter, T.: SAGE II measurements of stratospheric aerosol properties at non-volcanic levels, Atmos. Chem. Phys., 8, 983-995, https://doi.org/10.5194/acp-8-983-2008, 2008.

Thomason, L. W., Moore, J. R., Pitts, M. C., Zawodny, J. M., and Chiou, E. W.: An evaluation of the SAGE III version 4 aerosol extinction coefficient and water vapor data products, Atmos. Chem. Phys., 10, 2159-2173, https://doi.org/10.5194/acp10-2159-2010, 2010.

Thomason, L. W., Ernest, N., Millán, L., Rieger, L., Bourassa, A., Vernier, J.-P., Manney, G., Luo, B., Arfeuille, F., and Peter, T.: A global space-based stratospheric aerosol climatology: 1979-2016, Earth Syst. Sci. Data, 10, 469-492, https://doi.org/10.5194/essd-10-469-2018, 2018. 
Trepte, C. R. and Hitchman, M. H.: Tropical stratospheric circulation deduced from satellite aerosol data, Nature, 355, 626-628, https://doi.org/10.1038/355626a0, 1992.

Trickl, T., Giehl, H., Jäger, H., and Vogelmann, H.: 35 yr of stratospheric aerosol measurements at Garmisch-Partenkirchen: from Fuego to Eyjafjallajökull, and beyond, Atmos. Chem. Phys., 13, 5205-5225, https://doi.org/10.5194/acp-13-5205-2013, 2013.

Turco, R. P., Whitten, R. C., Toon, O. B., Pollack, J. B., and Hamill, P.: OCS, stratospheric aerosols and climate, Nature, 283, 283285, https://doi.org/10.1038/283283a0, 1980.

Vaughan, M. A., Powell, K. A., Kuehn, R. E., Young, S. A., Winker, D. M., Hostetler, C. A., Hunt, W. H., Liu, Z., McGill, M. J., and Getzewitch, B. J.: Fully automated detection of cloud and aerosol layers in the CALIPSO lidar measurements, J. Atmos. Ocean. Tech., 26, 2034-2050, https://doi.org/10.1175/2009JTECHA1228.1, 2009.

Vaughan, M. A., Pitts, M., Trepte, C., Winker, D., Detweiler, P., Garnier, A., Getzewich, B., Hunt, W., Lambeth, J., Lee, K.-P., Lucker, P., Murray, T., Rodier, S., Tremas, T., Bazureau, A., and Pelon, J.: Cloud-Aerosol LIDAR Infrared Pathfinder Satellite Observations (CALIPSO) data management system data products catalog, Release 4.10, NASA Langley Research Center Document PC-SCI-503, Hampton, Va, USA, 2016.

Vernier, J. P., Pommereau, J. P., Garnier, A., Pelon, J., Larsen, N., Nielsen, J., Christiansen, T., Cairo, F., Thomason, L. W., Leblanc, T., and McDermid, I. S.: Tropical stratospheric aerosol layer from CALIPSO lidar observations, J. Geophys. Res., 114, D00H10, https://doi.org/10.1029/2009JD011946, 2009.

Vernier, J.-P., Thomason, L. W., Pommereau, J.-P., Bourassa, A., Pelon, J., Garnier, A., Hauchecorne, A., Blanot, L., Trepte, C., Degenstein, D. and Vargas, F., Major influence of tropical volcanic eruptions on the stratospheric aerosol layer during the last decade, Geophys. Res. Lett., 38, L12807, https://doi.org/10.1029/2011GL047563, 2011a.

Vernier, J.-P., Thomason, L. W., and Kar, J., CALIPSO detection of an Asian tropopause aerosol layer, Geophys. Res. Lett., 38, L07804, https://doi.org/10.1029/2010GL046614, 2011 b.

Vernier, J.-P., Fairlie, T. D., Murray, J. J., Tupper, A., Trepte, C., Winker, D., Pelon, J., Garnier, A., Jumelet, J., Pavolonis, M., Omar, A. H., and Powell, K. A.: An advanced system to monitor the 3D structure of diffuse volcanic ash clouds, J. Appl. Meteorol. Clim., 52, 2125-2138, https://doi.org/10.1175/JAMC-D-120279.1, 2013.
Vernier, J.-P., Fairlie, T. D., Deshler, T., Natarajan, M., Knepp, T., Foster, K., Weinhold, F. G., Bedka, K. M., Thomason, L., and Trepte, C.: In situ and space based observations of the Kelud volcanic plume: The persistence of ash in the lower stratosphere, J. Geophys. Res., 121, 11104-11118, https://doi.org/10.1002/2016JD025344, 2016.

Winker, D. M., Pelon, J., Coakley, Jr., J. A., Ackerman, S. A., Charlson, R. J., Colarco, P. R., Flamant, P., Fu, Q., Hoff, R., Kittaka, C., Kubar, T. L., Le Treut, H., McCormick, M. P., Mégie, G., Poole, L., Powell, K., Trepte, C., Vaughan, M. A., and Wielicki, B. A.: The CALIPSO Mission: A Global 3D View Of Aerosols And Clouds, B. Am. Meteorol. Soc., 91, 1211-1229, https://doi.org/10.1175/2010BAMS3009.1, 2010.

Winker, D. M., Liu, Z., Omar, A., Tackett, J., and Fairlie, D.: CALIOP observations of the transport of ash from the Eyjafjallajökull volcano in April 2010, J. Geophys. Res., 117, D00U15, https://doi.org/10.1029/2011JD016499, 2012.

Winker, D. M., Tackett, J. L., Getzewich, B. J., Liu, Z., Vaughan, M. A., and Rogers, R. R.: The global 3-D distribution of tropospheric aerosols as characterized by CALIOP, Atmos. Chem. Phys., 13, 3345-3361, https://doi.org/10.5194/acp-133345-2013, 2013.

Young, S. A. and Vaughan, M. A.: The retrieval of profiles of particulate extinction from Cloud Aerosol Lidar Infrared Pathfinder Satellite Observations (CALIPSO) data: Algorithm description, J. Atmos. Ocean. Tech., 26, 1105-1119, https://doi.org/10.1175/2008JTECHA1221.1, 2009.

Young, S. A., Vaughan, M. A., Kuehn, R. E., and Winker, D. M.: The retrieval of profiles of particulate extinction from Cloud-Aerosol Lidar Infrared Pathfinder Satellite Observations (CALIPSO) data: Uncertainty and error sensitivity analyses. J. Atmos. Ocean. Tech., 30, 395-428, https://doi.org/10.1175/JTECH-D-12-00046.1, 2013.

Young, S. A., Vaughan, M. A., Garnier, A., Tackett, J. L., Lambeth, J. D., and Powell, K. A.: Extinction and optical depth retrievals for CALIPSO's Version 4 data release, Atmos. Meas. Tech., 11, 5701-5727, https://doi.org/10.5194/amt-11-5701-2018, 2016.

Young, S. A., Vaughan, M. A., Garnier, A., Tackett, J. L., Lambeth, J. D., and Powell, K. A.: Extinction and optical depth retrievals for CALIPSO's Version 4 data release, Atmos. Meas. Tech., 11, 5701-5727, https://doi.org/10.5194/amt-11-5701-2018, 2018. 